Published in final edited form as:

Annu Rev Pathol. 2016 May 23; 11: 251-281. doi:10.1146/annurev-pathol-012615-044506.

\title{
Disorders of Vascular Permeability
}

Cindy Park-Windhol ${ }^{1,2}$, Patricia A. D'Amore ${ }^{1,2,3}$

${ }^{1}$ Schepens Eye Research Institute, Massachusetts Eye and Ear, Boston, Massachusetts 02114;

2Department of Ophthalmology, Harvard Medical School, Boston, Massachusetts 02115

${ }^{3}$ Department of Pathology, Harvard Medical School, Boston, Massachusetts 02115

\section{Abstract}

The endothelial barrier maintains vascular and tissue homeostasis and modulates many physiological processes, such as angiogenesis. Vascular barrier integrity can be disrupted by a variety of soluble permeability factors, and changes in barrier function can exacerbate tissue damage during disease progression. Understanding endothelial barrier function is critical for vascular homeostasis. Many of the signaling pathways promoting vascular permeability can also be triggered during disease, resulting in prolonged or uncontrolled vascular leak. It is believed that recovery of the normal vasculature requires diminishing this hyperpermeable state. Although the molecular mechanisms governing vascular leak have been studied over the last few decades, recent advances have identified new therapeutic targets that have begun to show preclinical and clinical promise. These approaches have been successfully applied to an increasing number of disease conditions. New perspectives regarding how vascular leak impacts the progression of various diseases are highlighted in this review.

\section{Keywords}

barrier; endothelium; junctions; permeability; angiogenesis

\section{INTRODUCTION}

Regulation of endothelial barrier function is critical for vascular function and integrity.

Whereas single cells exchange gases and small molecules with their environment through diffusion, the vertebrate vasculature is permeable, which is important for the maintenance of normal fluid homeostasis and adequate gas exchange. Vascular permeability is a complex process and is influenced by many different variables. Factors that impact vascular permeability include (a) the intrinsic properties of the microvessels involved (e.g., capillaries and venules); (b) the size, shape, and charge of the extravasating molecules (water and solutes); (c) the anatomic pathways through which molecules cross the endothelial barrier, such as the channels, fenestrations or vesicles within individual endothelial cells

cindy_windhol@meei.harvard.edu .

DISCLOSURE STATEMENT

The authors are not aware of any affiliations, memberships, funding, or financial holdings that might be perceived as affecting the objectivity of this review. 
(transcellular) or the junctional complexes between adjacent endothelial cells (paracellular); (d) the time course over which permeability is measured; and (e) the specific vascular bed that is being investigated. Whereas transport of protein and lipids via transcellular routes contributes to the maintenance of vascular homeostasis, pathological vascular leak takes place largely by paracellular routes (1).

\section{Endothelial barrier function:}

the integrity of the endothelial structure, which undergoes changes at the cytoskeleton, cell-cell junction complexes, and cell attachments to extracellular matrix and basement membrane

\section{Transcellular:}

describes the transport of solutes through a cell, including passage through both the apical membrane and basolateral membrane

\section{Paracellular:}

describes the transfer of substances across an epithelium via passage through the intercellular space

Angiogenesis is the sprouting of new capillaries from preexisting vessels. Under physiological conditions, angiogenesis is an essential biological process that satisfies the increasing metabolic demand for nutrients and oxygen in rapidly expanding tissues (2). In adults, physiological angiogenesis occurs during reproduction, tissue remodeling (such as in adipose expansion and exercise) and wound repair; under these circumstances, the new vessel growth is local and limited (3). In contrast, the neovascularization that occurs under pathological conditions generally lacks the same spatial and temporal control. Angiogenesis plays a central role in cancer and many non-neoplastic diseases, such as rheumatoid arthritis, atherosclerosis, diabetic retinopathy, and age-related macular degeneration (AMD) (4). In most of these conditions, the new vessels are tortuous, display abnormal mural cell investment, and are hyperpermeable. The leakage of plasma proteins, in turn, leads to remodeling of the extracellular matrix (ECM) and tissue damage (5).

\section{Angiogenesis:}

the physiological process through which new blood vessels form from preexisting vessels

\section{Age-related macular degeneration (AMD):}

the leading cause of severe vision loss in people over age 60 , which afflicts the central macula 
Thus, abnormal control of this critical function may have devastating consequences. For example, solid tumors release factors that promote the growth of disorganized and leaky blood vessel networks that display disturbed blood flow, inflammatory cell infiltration, and tumor cell extravasation (6). The processes of vascular permeability and angiogenesis are regulated by a delicate balance of polypeptide factors and inhibitors (7). This review focuses on permeability characteristics of normal and pathological microvessels and on the mechanisms thought to control permeability, and concludes with possible implications for therapeutics.

New blood vessels form by two distinct mechanisms: vasculogenesis and angiogenesis (8, 9). In vasculogenesis, endothelial cell precursors known as angioblasts associate to form a network of primitive vessels. Cords lacking lumens are first formed, and these then remodel into patent vessels via tubulogenesis (9). In angiogenesis, new blood vessels form from the existing blood vessels, generally venules, by budding and sprouting. Whereas new blood vessels that form during development do not generally appear to be leaky, vessels associated with pathologies display greatly increased permeability. Initially described in 1935, and later confirmed in 1946, permeability was demonstrated when dyes leaked out of the capillaries of the developing amphibian tail (10) and during wound healing (11). Ultrastructural studies of wound healing models revealed that intravenous injection of a large molecular weight tracer, colloidal carbon, led to its deposition in the interstitium (12).

Today, the hyperpermeable nature of neovessels is recognized as a cardinal feature of abnormal angiogenesis. Although the vast majority of studies have demonstrated an increase in vascular permeability during pathologies such as heart disease, stroke, cancer, and ocular diseases, the regulation of vascular permeability is also critical during normal physiological angiogenesis, including exercise-induced neovascularization, hair growth, wound repair, and the female reproductive cycle.

\section{ULTRASTRUCTURAL CHANGES}

\section{Structure of Endothelial Layers}

Virtually all tissues (with the exception of the cornea, the lens, the vitreous humor, and cartilage) are supplied by a vasculature that delivers nutrients and remove waste products. The majority of transport occurs across capillaries; the narrow caliber of capillaries facilitates efficient transfer of oxygen and molecules, and their branching structure provides an expanded surface area. Gases, hydrophobic molecules and small hydrophilic molecules pass through capillaries freely, whereas circulating macromolecules are unable to cross the lipid membranes and are transported across capillaries only through bulk fluid phase transfer. The first site of fluid extravasation is the endothelium, the cells that line the entire vascular tree. The endothelium - at various levels of the vascular tree and in different microvascular beds-differs in structure and function. Endothelial cells are typically elongated in shape and have a surface coat termed a glycocalyx, a negatively charged glycosaminoglycan layer (13). Endothelial cells, which are anchored to a basement membrane by integrins, can be either continuous or fenestrated, reflecting their physiological function (14). 


\section{Endothelium:}

a thin layer of epithelial cells lining the insides of the blood vessels

The capillary endothelium of the central nervous system, including the retina, is the site of the blood-brain barrier, a filtering mechanism between the brain and the blood (15), which forms an effective barrier to fluid transfer (16). Extensive intercellular tight junctions between endothelial cells contribute to this, as do a very low level of transcellular vesicle transport and a continuous basement membrane, all of which restrict the movement of fluid and molecules into the tissue. Other capillary beds with a continuous endothelial layer include those of the heart, connective tissue, and muscle. In contrast, a number of capillary beds are characterized by discontinuous endothelium, including tissues whose functions are characterized by secretion, filtration, or particularly high vascular flow, such as the kidney, whose vasculature is fenestrated.

\section{Vascular Barrier Organization}

The structure of the vessels varies depending on their location in the vasculature and reflects both genetic and environmental influences. Larger vessels (arteries, arterioles, veins, and venules) consist of an endothelial cell lining with variable layers of smooth muscle cells, whereas capillaries and postcapillary venules have associated pericytes, the microvascular equivalent of smooth muscle cells. The passage of macromolecules, fluids, and cells through the endothelial barrier is affected by many different variables including the intrinsic properties of the microvessels involved (e.g., capillaries and venules); the size, shape, and charge of extravasating molecules (water and solutes); and the anatomic pathways through which molecules cross the endothelial cell barrier (transcellular versus paracellular) (Figure $1)$.

Transcellular transport.-Transcellular pathways involve caveolae, vesiculo-vacuolar organelles (VVOs), and fenestrae. Small molecules (less than $3 \mathrm{~nm}$ ) are commonly transported by a transcellular route, which requires a system of trafficking vesicles-VVOs. The vesicles or vacuoles of VVOs vary in size from caveolae-sized vesicles to vacuoles with volumes as much as ten-fold larger (17). Several permeability factors such as vascular endothelial growth factor (VEGF)-A and histamine have been demonstrated to activate VVOs (18). The VVOs rely on caveolin-1 function for albumin transport, for example, which transports fatty acids, and vitamins. Of note, caveolin-1 plays a dual regulatory role in microvascular permeability in that it stabilizes caveolae structure, allowing for transcytosis, but also acts as a negative regulator through endothelial nitric oxide synthase (19).

\section{Vesiculo-vacuolar organelles (VVOs):}

endothelial cell permeability structures that provide the major route of macromolecule extravasation at sites of increased vascular permeability induced by VEGF 


\section{Fenestrae:}

small pores in endothelial cells that allow for rapid exchange between blood vessels and surrounding tissue

\section{Vascular endothelial growth factor (VEGF):}

a potent angiogenic factor first described as an essential growth factor for vascular endothelial cells, upregulated in many tumors and other angiogenic diseases

Paracellular transport.-Whereas the homeostatic transport of proteins and lipids occurs largely via transcellular routes, pathological vascular leakage usually takes place by paracellular routes (1). Cells and macromolecules larger than $3 \mathrm{~nm}$ escape the blood vessel via the paracellular pathway, which is mediated by the coordinated opening and closing of the endothelial cell-cell junctions. The endothelial barrier is largely maintained by adherens and tight junctions. Among the adherens junction proteins, the most notable is vascular endothelial (VE-)cadherin (20). In mice, VE-cadherin gene deletion results in early embryonic lethality due to massive vascular defects, whereas loss of its function in adults provokes a hyperpermeability phenotype $(21,22)$. In addition, in vivo disruption of VE-cadherin with a function-blocking antibody leads to vascular leak and hemorrhage (23). Of note, a number of other adhesive proteins accumulate in or close to adherens junctions including $\mathrm{N}$-cadherin, platelet-endothelial cell adhesion molecule and junctional adhesion molecules (JAMs). JAMs are believed to support leukocyte recruitment and extravasation under inflammatory conditions. They appear to promote leukocyte movement through intercellular junctions, thus playing an important role in vascular permeability and leukocyte transmigration. For a more detailed review on the role of JAMs in inflammation and vascular pathology see Reference 24 .

\section{Vascular endothelial (VE-)cadherin:}

a calcium-dependent adhesive molecule, exclusively and constitutively expressed in endothelial cells

Tight junctions bind endothelial cells to one another as a monolayer, blocking diffusion along the apical and basolateral poles (25). Tight junctions are composed of transmembrane adhesion proteins, occludins and claudins, JAM family proteins, and intracellular connectors, including zona occludens (ZO)-1, 2, and 3. In contrast to VE-cadherin, deletion of the claudin-5 gene does not impair murine embryonic development but rather leads to postnatal death caused by defective blood-brain barrier (26). Thus, whereas VE-cadherin is instrumental in vascular barrier integrity, the claudins may have a more restricted role (27). Nevertheless, adherens and tight junctions functionally and structurally influence cell polarity, differentiation, survival, and the maintenance of tissue integrity. 


\section{Zona occludens (ZO):}

tight junctions formed by the fusion of integral proteins of the lateral cell membranes of adjacent epithelial cells, limiting transepithelial permeability

Vascular endothelial cells are anchored to the ECM through integrin-based adhesion complexes, referred to as focal adhesions. Integrins act as a bridge between the ECM and the actomyosin cytoskeleton (28), allowing the endothelium to adapt to extracellular signals and cues (e.g., shear stress and secreted molecules). Rho-GTPase activation, stress fiber formation, and actomyosin contraction are finely tuned through integrin adhesion and modulate junctional integrity (29). A recent study demonstrated that the integrin-associated focal adhesion tyrosine kinase (FAK) contributes to impairment of vascular barrier formation (30). VEGF-induced FAK activation was shown to lead to VE-cadherin/FAK interaction in association with $\beta$-catenin phosphorylation on tyrosine $\mathrm{Y}-142$, resulting in dissociation of VE-cadherin and $\beta$-catenin, opening of junctions, and disruption of the endothelial barrier. Whereas adherens and tight junctions maintain the endothelial barrier, gap junctions connect adjacent endothelial cells as well as endothelial cells and mural cells (pericytes and smooth muscle cells) $(31,32)$. Water, ions, and small signaling molecules can be transferred via gap junctions, but gap junctions do not appear to contribute significantly to the establishment or maintenance of vascular barriers.

\section{LEVELS OF VASCULAR PERMEABILITY}

Vascular permeability is essential for homeostasis and varies in response to different physiological stimuli (temperature, exercise, etc.). There are important differences between the basal permeability and the changes that occur during pathology including whether the hyperpermeability is acute or chronic, the composition of extravasate, and the anatomic pathways that solutes follow in crossing vascular barriers. Under normal circumstances, water, lipophilic solutes (e.g., $\mathrm{O}_{2}$ and $\mathrm{CO}_{2}$ ), and small solutes are exchanged at the level of the capillary, driven by diffusion and plasma protein extravasation. Small molecules pass between endothelial cells, are transported via receptor-mediated transcytosis, or may cross through the fenestrae. Larger proteins, such as albumin, that are unable to pass between intact endothelial cells are instead transported via caveolae. The plasma membrane is heavily decorated with small, uncoated vesicles, which constitute this specialized microdomain (33). Most caveolae are connected to the luminal and abluminal plasma membranes-with few located on the lateral aspects of the cell. Based on studies using tracers, it was postulated that caveolae shuttled across capillary endothelium carrying plasma fluid and proteins (34). The role of caveolae, however, has been called into question by the findings that mice deficient for caveolin-1 (which therefore lack caveolae) are able to clear albumin more rapidly than their wild-type counterparts. Of note, caveolin-1-deficient mice exhibited 10$20 \%$ of the uncoated caveolae-sized vesicles present in wild-type mice although these vesicles did not stain for caveolin-1 (35).

In contrast to basal conditions, the protein content of the fluid that extravasates under circumstances of both acute and chronic vascular hyperpermeability approaches that of 
plasma. The leak that accompanies acute hyperpermeability takes place at the level of the postcapillary venules (36). In contrast to the flattened endothelium of the capillary, postcapillary venules are lined by tall, cuboidal endothelium that utilizes VVOs for plasma extravasation $(18,37,38)$. Although little is known about the mechanism of VVO function, it has been demonstrated using macromolecular tracers that exposure to permeability agents such as histamine or VEGF can induce the formation of interconnected VVO vesicles and vacuoles from the vascular lumen to the albumen, providing a transcellular pathway for plasma and plasma protein extravasation (18).

The leak that characterizes chronic hyperpermeability induces profound changes in venular structure and function. A category of new vessels termed "mother" vessels appears to be involved in pathological angiogenesis (39). Mother vessels are highly abnormal vascular structures that form in tumors and in other cases of abnormal neovascularization $(39,40)$. These vessels develop within hours after injection of tumor cells into mice, and are also seen in healing wounds and in tissues from nude mice that have been injected with an adenovirus expressing VEGF-A ${ }^{164}(39,40)$.

Structurally, mother vessels are dilated sinusoids that arise from preexisting normal venules by a process that involves basement membrane degradation, pericyte detachment, endothelial cell thinning, and a significant increase in lumen size. Two important components of the basement membrane, collagen IV and the laminin $\beta 1$ chain, have been reported to be degraded in the developing mother vessels both in tumors and after adenoviral-VEGF-A ${ }^{164}$ injections (41). Of note, experimentally induced pericyte loss in the adult murine retinal microvasculature has been shown to be associated with microvascular permeability (Figure 2) and microaneurysms (42). In addition, formation of mother vessels involves reduction in several endogenous cysteine protease inhibitors and cystatin $\mathrm{A}, \mathrm{B}$, and C. Pericytes of venules that were remodeled into mother vessels have been shown to have increased cathepsin expression and activity (41).

\section{REGULATORS OF VASCULAR PERMEABILITY}

\section{Vascular Endothelial Growth Factor}

In the 1980s, vascular permeability factor (43), also known as VEGF (44), was identified and shown to be a key regulator of permeability (45). The VEGF family comprises a number of closely related ligands, including VEGF-A, B, C, D, and E and placental growth factor. Among these, VEGF-A (hereafter referred to as VEGF) is the best characterized. Various cell types, including arterial endothelial cells (46), smooth muscle cells, fibroblasts, a wide range of epithelial cells (47), parenchymal cells of a number of tissues and organs (e.g., liver and skeletal muscle) (47) and immune cells (macrophages, lymphocytes, neutrophils, eosinophils, and mast cells) produce and release VEGF, where it can act upon endothelial cells as well as a variety of nonendothelial cells (48). In addition, VEGF, which is encoded by a single gene, is differentially spliced into a number of isoforms-four common and three rare isoforms that vary from 121 to 207 amino acids in humans (49-52). Evidence from mice that have been engineered to produce single VEGF isoforms indicates that the isoforms serve distinct roles. It has been shown that hypoxia and other stress conditions induce the expression of VEGF by many cell types; moreover, VEGF is highly expressed in 
tissues undergoing growth or remodeling - for example, during cancer, atherosclerosis, and remodeling of the female reproductive cycle.

\section{Vascular permeability factor:}

a glycoprotein that increases blood vessel permeability, endothelial cell growth, and angiogenesis, contributing to the increased neovascularization and vessel permeability associated with tumor vasculature

Members of the VEGF family signal through tyrosine kinase receptors (VEGFRs), in particular VEGFR1 (flt-1) (53), VEGFR2 (flk1 in the mouse, KDR in the human) (54), VEGFR3 (flt4) (55), and neuropilin (56). VEGF interacts with both VEGFR1 and -R2, but only VEGFR2 is directly involved in normal and pathological vascular permeability (57). Binding of VEGF to its VEGFR2 induces their dimerization and activation of an intracellular tyrosine kinase activity, recruitment of SH2 domain binding proteins, and subsequent downstream signaling through multiple common signaling pathways (55). VEGFR1 is reported to act as a negative regulator of VEGFR2 signaling by sequestering VEGF.

VEGF stimulation of endothelial cells in culture has been shown to stimulate virtually all known signaling pathways, with more than 50 different signaling molecules identified as being activated (Table 1). For instance, VEGF stimulates phospholipase $\mathrm{C}$ and A (58), protein kinase B (Akt) and PI3 kinase (59). VEGF is an endothelial mitogen, a powerful vascular permeability agent (60), and a potent vasodilator (61). It increases migration of endothelial cells, and has effects on the pericytes that surround endothelial cells (62) and on matrix metalloproteinases secretion by endothelial cells (63). Systemic VEGF administration results in hypotension via its effects on nitric oxide (64), whereas local secretion leads to vascular leak (65) and increased angiogenesis (66). Recently it has been shown that VEGF induces unequal responses depending on whether it acts on the luminal or abluminal side of neural microvascular endothelial cells; increasing VEGF levels within the lumen did not affect baseline permeability, whereas exposure to VEGF from the tissue side led to a rapid increase of permeability (67). In addition, cerebral and retinal vascular permeability was completely refractory to circulating VEGF, whereas the lung vasculature responded to circulating VEGF with enhanced permeability and p38 activation (67).

\section{Vascular Endothelial Cadherin}

VEGF activation of endothelial cells in culture results in phosphorylation and disassembly of VE-cadherin, one of the principal signaling and structural proteins associated with adherens junctions (115). VE-cadherin phosphorylation is initiated early (within $5 \mathrm{~min}$ ) and peaks at $30 \mathrm{~min}$ after VEGF stimulation, strongly implicating it in the regulation of permeability. In support of this concept, there is considerable evidence demonstrating the regulation of adherens junctions during VEGF induction of vascular permeability. VEGF has also been shown to promote the phosphorylation of VE-cadherin and of its binding partners $\beta$-catenin, plakoglobin, and p120, in a Src-dependent mechanism (116). Consistent with this, VE-cadherin is not phosphorylated in Src-deficient mice (116). Furthermore, VE-cadherin 
has been reported to associate with VEGFR2, an association that inhibits VE-cadherin phosphorylation and internalization (117). This interaction is speculated to potentiate the phosphorylation of VEGFR2 via adherens junction components by Src, thereby leading to impaired endothelial barrier integrity (118).

The association between VE-cadherin and VEGFR2 also contributes to VE-cadherininduced contact inhibition of cell growth, an event that requires the $\beta$-catenin, but not the p120-catenin, binding domain of VE-cadherin (117). In addition, VEGF mediates VE-cadherin phosphorylation and internalization via the activation of Src, the guanine nucleotide exchange factor Vav2, the Rho-GTPase Rac, and p21-activated kinase (PAK) - a downstream effector molecule of Rac that has been implicated in cytoskeletal remodeling and cell motility (119). VE-cadherin is the target of a plethora of signaling events, which can provoke endothelial barrier disruption and vascular permeability increase (Table 2). Endothelial permeability is also reported to be regulated by changes in the expression of the components of adherens and tight junctions (120); mice lacking serum response factor, which is important for VE-cadherin expression (121), displayed reduced VE-cadherin expression.

\section{Sphingosine-1-Phosphate}

Sphingosine-1-phosphate (S1P), an important regulator of postcapillary venule permeability, acts through two receptors, $\mathrm{S}_{1} \mathrm{P}_{1}$ and $\mathrm{S}_{1} \mathrm{P}_{2}$, which are differentially expressed in various vascular endothelial beds. Detailed features of the S1P receptors involved in vascular permeability are shown in Table 3. S1P receptors mediate a range of vascular functions, such as vascular morphogenesis and maturation, cardiac function, vascular permeability, and tumor angiogenesis (150). It is well established that $\mathrm{S} 1 \mathrm{P}$, acting via the $\mathrm{S}_{1} \mathrm{P}_{1}$ receptor, promotes endothelial cell barrier integrity. Intravenously delivered S1P attenuates vascular barrier dysfunction in murine and canine models of acute lung injury (150). Furthermore, FTY720, a high affinity agonist of S1P receptors, induces adherens junction assembly in the endothelial cell monolayer whereas oral FTY720 administration in mice potently blocks VEGF-induced dermal vascular permeability in vivo (151). More recently, bone-marrow derived progenitor cells from wild-type mice were shown to act though the S1P pathway to enhance endothelial barrier function as well as prevent increased vascular permeability and edema formation $(152,153)$.

\section{Sphingosine-1-phosphate (S1P):}

a major regulator of vascular and immune systems formed by the metabolism of sphingomyelin

In endothelial cells, the activation of the $\mathrm{S}_{1} \mathrm{P}_{2}$ receptor results in disruption of adherens junctions and increased paracellular permeability, whereas administration of a $\mathrm{S}_{2} \mathrm{P}_{2}$ receptor antagonist significantly inhibits $\mathrm{H}_{2} \mathrm{O}_{2}$-induced permeability in the rat lung perfused model (151). Induction of retinal hypoxia in mouse retinas that lack the $\mathrm{S}_{1} \mathrm{P}_{2}$ receptor leads to significantly decreased inflammatory cell infiltration and enhanced revascularization of 
the retina tissue, indicating that the $\mathrm{S}_{1} \mathrm{P}_{2}$ receptor activates inflammatory pathways that facilitate vascular permeability and pathological angiogenesis (175).

\section{Angiopoietin-1}

Angiopoietin (Ang)-1, a ligand of the Tie-2 receptor, blocks vascular permeability; mice that overexpress Ang-1 are resistant to proinflammatory agents (176). In the mature vasculature, Ang-1 acts by inducing Rac1 activation and RhoA inhibition. p190 RhoGAP, a GTPase regulatory protein, is phosphorylated by Ang-1, requires Rac1 activation, and is necessary for RhoA inhibition (177). Thus, Ang-1 has been shown to protect against endotoxinmediated vascular leak by regulating the endothelial cytoskeleton through coordinated and opposite effects on the Rho GTPases Rac1 and RhoA. At the cellular level this may translate to the regulation of intercellular gaps, as adenoviral delivery of Ang-1 has been demonstrated to attenuate leakage from bradykinin-induced pulmonary permeability by reducing the number and size of interendothelial gaps (178). Whereas Ang-1 reduces a VEGF-stimulated increase in blood-brain barrier permeability by the upregulation of ZO-2, a component of tight junctions (179), Ang-2, a naturally occurring antagonist of Ang-1, leads to microvascular destabilization both in an in vitro model (180) as well as in the blood-brain barrier in vivo (181).

\section{Angiopoietin (Ang)-1:}

a protein with important roles in vascular development and angiogenesis, encoded by the gene ANGPT1

\section{Rho Family GTPases in Permeability}

Members of the Rho family GTPases regulate endothelial barrier function; Rho family GTPases influence the actin cytoskeleton, directly modulating the integrity of endothelial cell-cell junctions. Rho A can lead to the disruption of barrier function through activation of Rac1 whereas activation of Cdc42 stabilizes cell-cell junctions. With expanding knowledge of Rho family GTPase regulation, new therapeutic opportunities to inhibit the propermeability activity of RhoA and/or enhance the antipermeability of Rac1 and Cdc42 are possible. Thrombin increases Rho activation, whereas a delayed activation of $\mathrm{Cdc} 42$ contributes to the reassembly of interendothelial junctions and barrier integrity (182).

\section{Rho family GTPases:}

a small family of $\mathrm{G}$ proteins that have been shown to regulate many aspects of intracellular actin dynamics

Rac1 is important in the assembly and disruption of adherens and tight junctions. GTPbound Rac1 and Cdc42 bind to and facilitate the autophosphorylation of PAK, which induces barrier breakdown, whereas blockade of PAK activity preserves barrier integrity (183). Downstream of PAK, activation of extracellular signal-regulated kinase is required for increased vascular permeability, and PAK-mediated extracellular signal-regulated kinase activation requires the formation of a complex containing PAK, PIX, and GIT1 (184). Thus, 
blockade of the binding of PAK to PIX inhibits edema during acute lung injury (184). In addition, whereas PAK is activated in atherosclerosis-prone regions of arteries, inhibition of PAK phosphorylation reduces permeability during atherosclerosis in vivo (185). Of note, Rac, in particular, appears to be linked to VEGF-induced fenestration formation (186).

\section{Transforming Growth Factor- $\beta 1$}

Transforming growth factor (TGF)- $\beta 1$ is a multifunctional growth factor that is a wellestablished modulator of vascular cells (187). In vitro studies indicate that TGF- $\beta 1$ is activated upon contact between endothelial and mesenchymal cells (188) and that it mediates a variety of actions associated with vessel maturation including inhibition of endothelial cell proliferation and migration, induction of pericyte differentiation, and production of basement membrane (188-190). TGF- $\beta$ signals through TGF $\beta$ RII to recruit and phosphorylate TGF $\beta$ RI, with subsequent downstream recruitment of smad transcription factors (191). Blockade of TGF- $\beta$ signaling by systemic expression of endoglin (TGF $\beta$ RIII) results in breakdown of the blood-retinal barrier, characterized by a decreased association between the tight junction proteins ZO-1 and occludin. Recently, it was reported that endoglin deficiency in vivo leads to an increase in endothelial cell permeability through constitutive activation of RhoA and destabilization of the endothelial barrier function. Destabilizing factor thrombospondin-1 and its receptor-like protein tyrosine phosphates are increased, whereas stabilizing factors VEGFR2 and VE-cadherin are decreased, suggesting that endoglin deficiency leads to endothelial cell hyperpermeability (192). The TGF $\beta R I$ receptors ALK5 and ALK1 were shown to be involved in the regulation of permeability as signaling through ALK5-stabilized vascular endothelium, whereas signaling through ALK1 limited ALK5 signaling, leading to vascular destabilization $(193,194)$. These findings implicate TGF- $\beta$ in maintaining the vascular barrier integrity and function of the normal retinal microvasculature.

\section{Transforming growth factor (TGF)- $\beta 1$ :}

a multifunctional set of peptides that controls proliferation, differentiation, and other functions in many cell types

In primary breast tumors, TGF- $\beta 1$ activity is associated with an increased risk of lung metastasis (195). Indeed, Ang-related protein 4 (Ang-4), a target of TGF- $\beta 1$, disrupts endothelial cell-cell junctions, facilitating the extravasation of breast cancer cells (195). Moreover, TGF- $\beta 1$ induces the expression of VEGF in pericytes (196) and fibroblasts (197), whereas it inhibits Ang-1, an antipermeability factor, therefore exacerbating tumorassociated vascular leak (198).

\section{ASSESSMENT OF BARRIER FUNCTION IN CULTURED ENDOTHELIAL CELLS}

Because of the complexity of performing molecular or pharmacological manipulations to study barrier function in vivo, cultured endothelial cells are often used to model the microvascular endothelium, and most involve confluent endothelial cells cultured on porous 
membrane filters in transwell chambers. A number of in vitro assays have been developed to measure molecular flux (Table 4). The transwell assay is widely used to determine the transendothelial permeability of solutes (e.g., albumin, dextrans, and sucrose) across endothelial monolayers (199). These systems have a number of advantages including that they are easy to perform and avoid the complexities of living animals (described below). It goes without saying that such assays do not come without limitations. Generally, monolayers of cultured endothelial cells are not able to form barriers that are as tight as their in vivo counterparts. This difference is likely due to a number of variables including the fact that the cultures lack normal basement membrane (200), contributions from other cell types (e.g., pericytes or smooth muscle cells) are missing (18), and cytoplasmic vesicles and vacuoles, structures that are important for macromolecular extravasation, are not observed at the levels seen in vivo (201). In addition, the conditions of tissue culture are distinct from that experienced by the cells in vivo and involve the presence of serum and growth factors and the growth of cells on a plastic substratum that lead to changes in gene expression that differ from in vivo. As such, the kinetics of permeability in response to agents such as VEGF differs significantly from that of in vivo settings. In vivo leakage in response to a single exposure of VEGF begins rapidly and is fully complete within 20-30 min. In contrast, changes in permeability often develop more slowly in cultured endothelium and may continue over a period of hours.

Endothelial cell membranes are composed of lipophilic molecules (e.g., phospholipids and cholesterol) that restrict the passage of aqueous solutions and function as electrical insulators to maintain the physiological endothelial membrane electrical potential. Thus, the fluid-filled pores at cell-cell junctions can also function as electrical conductance pathways across the endothelium. In theory, an increase in the number of open pores can be correlated to a decrease in electrical resistance across the microvascular endothelium. The measurement of electrical resistance across microvessel walls [i.e., transendothelial electrical resistance (TER)] is relatively simple. Using transwells, TER is measured directly across the cell monolayer using an electrical resistance meter with probes placed into both the luminal and abluminal compartments. Barrier function is calculated based on impedance to the flow of small inorganic ions across the microvessel wall. An advantage of this model is that it also allows the examination of interactions between different cell types that form protective barriers and as such a coculture model is often used (Figure 3).

\section{Transendothelial electrical resistance (TER):}

a measurement that provides a quick and easy evaluation of blood-brain barrier integrity

Other quantitative methods for determining the TER include the use of fluorescently labeled dextran to characterize changes in endothelial cell permeability to higher molecular weight molecules. In this case, transfer is measured by relative fluorescence as well as by the use of an electrical cell-substrate impedance sensor (203), a device that quantifies cell density, migration, and electrical impedance. 
Electrical cell-substrate impedance sensor:

a noninvasive biophysical approach to monitor living animal cells in vitro

Thus, although in vitro systems to study vessel permeability have been well studied, these models have limited resemblance to real physiological structures and functions. In many cases, however, cultured endothelial cells are the only available model for testing mechanistic hypotheses related to cell signaling in control of microvascular barrier function, as it is often not technically possible to perform these kinds of experiments in vivo.

\section{EVALUATION OF VASCULAR LEAK IN MICE}

Miles Assay

The Miles assay has been widely used to assess and to quantify vascular permeability in vivo (204). Although this assay was originally developed using the skin of guinea pigs, it has since been adapted to a number of different mouse organs such as the liver and ear, to name a few (205). In brief, this assay uses an intravenously injected tracer, Evans blue, a dye that binds noncovalently to albumin, to measure dye accumulation at the test site (Figure 4). Permeability is defined by the amount of albumin-dye complex present at an indicated time point after Evans blue injection. Visual discoloration or bluing at the site of injection reflects leakage from the vascular compartment; quantitative measurements can also be made by extracting the dye from tissues and measuring it spectrophotometrically (206). Although the Miles assay is widely employed, there are some limitations to this assay. For one, it is not suitable for the assessment of vascular permeability in noninflamed tissue because the albumin (which is tagged by the tracer) does not traverse the vascular barrier in significant quantities in the absence of inflammation. Another major limitation is that the assay measures net accumulation of dye-albumin complex over a period of time, so that the return of extravasated molecules to the circulation, by way of either capillaries or lymphatics, is not considered. Regardless of these limitations, the Miles assay provides useful information regarding permeability of the vascular compartment of a specific tissue.

\section{First-Order Model of Albumin Kinetics Using a Dual Isotope Approach}

In instances where the vasculature undergoes pathological changes it is possible to measure both the content of a macromolecular tracer and the dye that has extravasated, allowing investigation of both structural and functional changes of the vasculature. This is achieved using a dual tracer method (e.g., combining ${ }^{131} \mathrm{I}$ - and ${ }^{125} \mathrm{I}$-albumin or Evans blue dye and ${ }^{125}$ I-albumin) (205), where the first tracer is used to measure total albumin accumulation over a course of $30 \mathrm{~min}$, and the second tracer, injected $5 \mathrm{~min}$ before tissue harvest, measures albumin that is present within the vasculature. The difference between these measurements allows for quantitation of intravascular plasma volume and the volume of leaked plasma.

\section{Ultrastructural Visualization of Permeability}

Structural alterations of the endothelium with increased permeability can be visualized by transmission electron microscopy (TEM). Initially, TEM was utilized to visualize the 
structural aspects of the vascular endothelium (200) but was later used to study vascular leakage from VEGF-stimulated and tumor-associated blood vessels (37). More recently, TEM was employed to show that heart or brain capillaries exposed to systemic VEGF respond with a series of events including development of gaps between adjacent endothelial cells and attraction of platelets to exposed basement membrane (118). Of note, assessment at the ultrastructural level can provide insights into the mechanism by which an agent promotes or blocks vascular leak.

\section{Evaluation of Vascular Leak Using Light Microscopy}

Taking advantage of the unique binding properties of specific lectins, labeling with Griffonia simplicifolia lectins is used to measure permeability in vivo. In this method, vascular leak is measured by light microscopy after perfusion with lectins; peroxidase is used to visualize the binding of lectin to specific locations during the permeability response in tissue sections of whole-mount preparations (207). In addition to lectins, extravasation of labeled tracers such as fluorescently labeled dextrans can also be employed to detect both vessel perfusion and leak. Dextrans of different sizes can be used to evaluate the contribution of different pathways to the leak response (i.e., fenestrations, caveolae, VVOs, endothelial gaps). Use of different sized microspheres or different molecular weight fluorescently-labeled dextran (4-70 kDa) can be applied to better assess the extent of endothelial leak. Depending on the molecular size, these tracers can be used to test both solute and ion permeability (low molecular weight dextrans) and protein permeability (high molecular weight dextrans). Movement of dextrans out of the plasma through the fenestrae and channels is relatively rapid (3-7 min). This can create transient concentration gradients in the pericapillary space centered on the fenestrated sectors of the capillary walls. Recently, passage of dextran larger than $70 \mathrm{kDa}$ was shown to be retained in skin blood vessels under homeostatic conditions, whereas under inflammatory conditions, the hyperpermeability was selectively induced in the postcapillary venules and dextran as large as 2,000 kDa leaked from the blood in vivo (208). Together, use of electron and light microscopic techniques offer valuable insights into the structural determinants of leakage within pathological samples.

\section{IMPLICATIONS OF VASCULAR PERMEABILITY DURING PATHOLOGY}

Under physiological conditions, microvascular permeability is tightly regulated. However, during a variety of pathologies, the disruption of the vascular barrier results in the release of potent permeability agents, as well as agents that recruit platelets and leukocytes to the affected site. Aberrant and uncontrolled vascular hyperpermeability can participate in the progression of many pathological states, such as chronic inflammatory diseases, diabetes, tumor angiogenesis, and retinal diseases. This section highlights current knowledge regarding how vascular leak impacts the progression of various diseases and examines the promise of new clinical therapies aimed at controlling excess permeability. Other review articles provide further details on angiogenic diseases (209), antiangiogenesis strategies (210), and preclinical and clinical advances of vessel normalization (6). The reader is referred to other excellent reviews to learn more about new therapeutic approaches that are currently being used for cancer and other angiogenic disorders (211-213). 


\section{Cancer and Metastasis}

Hypoxia is a principal driver of VEGF expression and is considered to be one of the primary inducers of increased vascular supply to tumors. The VEGF produced by tumor cells stimulates not only angiogenesis but also increased vascular permeability with resulting edema. Inhibition of VEGF has been shown to reduce the fluid accumulation in and around tumors, reducing morbidity or metastasis in experimental models (214-216). Since its approval by the US Food and Drug Administration (FDA) in 2006, the anti-VEGF agent bevacizumab $\left(\right.$ Avastin $^{\circledR}$ ) has been used in combination with drugs, chemotherapeutic agents, or other antibodies in an attempt to block tumor vascularization. In spite of initial hopes that antiangiogenesis would have high efficacy in tumor suppression, results in human cancer lack success. Bevacizumab, when administered with standard chemotherapy, results in a modest increase in survival (e.g., 2-5 months) in certain cancers (colorectal and lung) but not others (pancreatic and breast) $(217,218)$. Similarly, two broad-spectrum tyrosine kinase inhibitors that also target VEGF receptors (e.g., sunitinib and sorafenib) have also had limited success $(219,220)$. Although these therapies often prolong survival by a matter of months, they generally do not markedly extend life. A number of explanations have been offered for the modest effectiveness of anti-VEGF/VEGFR drugs in treating human cancers, whereas more potent effects are observed in tumor-bearing mice. One possibility is the need for better dosing strategies, as the fragility of cancer patients means that they cannot withstand the toxicities associated with the high dose therapy that can be used in tumor-bearing mice. Another reason could be that anti-VEGF/VEGFR therapy does not kill all tumor cells and the residual tumor cells that remain behind are rendered hypoxic and become stimulated, making increased amounts of VEGF-A that may overwhelm the anti-VEGF/VEGFR therapy and thus protect the cells from anti-VEGF drugs (221). Other explanations include vascular normalization, a period of time following anti-VEGF/VEGFR therapy in which tumor vessels normalize structurally and lose their hyperpermeability.

Despite the lack of success of anti-VEGF/VEGFR therapy for most cancers, the utility of VEGF antibodies in the treatment of ovarian carcinoma was initially explored in animal models where VEGF blockade was shown to inhibit the formation of ascites and slow tumor growth (222). The role of bevacizumab in the management of ovarian cancer has been examined in two randomized phase II trials: Gynecologic Oncology Group and Genentech AVF 2949; although there was a statistically significant improvement in progression-free survival, no improvement in overall survival was reported (223). In 2014, the FDA approved bevacizumab as a treatment for ovarian cancer. Of note, the FDA has also approved the anti-VEGF bevacizumab to treat glioblastoma, advanced nonsquamous, and non-small-cell lung cancer.

Although VEGF has been the most widely exploited target for antiangiogenic therapy, increased attention has been directed toward the Ang-Tie2 pathway, in particular by inhibiting Ang-1 and/or Ang-2 with monoclonal antibodies (224). Currently, there are a number of agents targeting the Ang/Tie2 axis under investigation in clinical trials. One example is AKB-9778, a selective inhibitor of vascular endothelial protein tyrosine phosphatase (VE-PTP), which promote maturation of tumor vessels by blunt tumor growth via Tie2 activation (225). Inhibition of Ang-2 has been shown to mitigate vascular 
leak syndrome in patients receiving interleukin (IL)-2 treatment. In addition, blocking endogenous hyaluronan with a hyaluronan-specific binding peptide has been reported as a novel means to prevent IL-2-induced vascular leak syndrome. The region of IL-2 that mediates the induction of vascular leak syndrome has been identified as a shared three-amino acid consensus motif, (x)D(y), believed to be responsible (226). Currently, an immunotoxin engineered to eliminate vascular leak syndrome is being used in preclinical models in combination with IL-2 to treat cancer (226).

\section{Ischemic Diseases}

Changes in blood-brain barrier permeability are a characteristic of ischemic stroke. Vascular permeability has been reported to precede spontaneous intracerebral hemorrhage in strokeprone spontaneously hypertensive rats (227). The edema associated with stroke is a primary cause of neuronal damage and also impedes recovery. Thus, inhibitors that reduce initial edema in the brain and heart have been shown in experimental mouse models to limit infarct size, increase function, and prolong survival. From a more mechanistic perspective, VEGF is produced following myocardial infarction or stroke in response to resultant hypoxia. Mice lacking the Src family kinases Src or YES proto-oncogene 1 do not exhibit vascular permeability in response to VEGF (228) and thus have reduced infarct size and edema following ischemic stroke. Similar protection is observed with use of VEGF antagonists or pharmacological Src family kinase inhibition (118).

\section{Pulmonary Diseases}

Pulmonary conditions that involve endothelial barrier hyperpermeability, including asthma, acute lung injury, and ventilator-induced lung injury, are associated with increased vascular permeability that, in the latter settings can result in pulmonary edema. It has been proposed that the increased vascular permeability in ventilator-induced lung injury is a result of an active endothelial response to mechanical strain, which induces signaling pathways that lead to vascular permeability. It has also been shown that lung injury activates different PI3Kmediated pathways that oppose each other and that the balance between these pathways determines the net effect on vascular permeability (229). Treatment with inhibitors of PI3K or Src family kinases can also reduce edema in the ventilated mouse lung, and activation of the PI3K-Akt-GSK3 $\beta$ pathway tends to limit the permeability response by preserving expression of $\beta$-catenin (229).

\section{Ocular Diseases}

Hypoxia has been demonstrated to induce production of VEGF by retinal endothelial cells, retinal pericytes, Muller cells, retinal pigment epithelial cells, and ganglion cells (230-235). Furthermore, experimental induction of retinal ischemia in both mouse and primate eyes has demonstrated retinal (232) and iris (236) neovascularization, respectively, that are associated with elevated levels of VEGF and that can be blocked by VEGF neutralizing antisera (237). The majority of severe visual loss in the United States results from complications associated with retinal neovascularization in patients with ischemic ocular diseases such as diabetic retinopathy, retinal vein occlusion, and retinopathy of prematurity. Diabetic retinopathy, for example, occurs when capillary loss from the retina leads to localized areas of retinal nonperfusion. The resultant hypoxia leads to the production of VEGF by cells 
in the ischemic retinal tissues, which leads to edema, leaky vessels and neovascularization causing disrupted vision. Anti-VEGF therapies are being widely used in the treatment of diabetic macular edema where it has been shown to be highly effective. VEGF neutralization is similarly efficacious as a therapy for central retinal vein occlusions as well as branch vein occlusions. However, the effect of anti-VEGF treatment for the management of retinopathy of prematurity is controversial because of the high level of active angiogenesis that is taking place in many, if not all, tissues and organs of these premature infants (238).

In the wet (or exudative) form of AMD, increased VEGF expression leads to proliferation of abnormal and highly permeable vessels from the choriocapillaris into the subretinal space. Whereas retinal blood vessels are part of the blood-brain barrier and have extremely low hydraulic conductivity (239), the choroidal vasculature has a very high permeability due to the presence of fenestrations in the endothelial cells (239). When newly forming and leaking choroidal vessels invade into the retinal space in the region of the macula, the fluid disrupts the retinal architecture, resulting in disruption of central vision. Intraocular injection of either bevacizumab, the variable fragment of a similar VEGF antibody (termed ranibizumab), or a VEGF-trap known as aflibercept, can initially reverse visual loss and restore vision (240) in a subset of patients.

Studies in rodents have begun to elucidate the function of VEGF in normal adult tissues. Systemic inhibition of VEGF using adenoviral expression of sFlt-1 leads to nonperfusion of vessels in the choroid plexus (47), death of photoreceptors that were shown to express VEGFR2 (241), and degeneration of the retinal pigment epithelium that was similarly demonstrated to express VEGFR2 (242). In addition, the choriocapillaris, as well as all of the other fenestrated vascular beds of the body, has been shown to be uniquely vulnerable to VEGF inhibition (243). Decreased fenestrations, vessel occlusion, and vessel regression were observed after intravitreal injection of anti-VEGF (bevacizumab) in primate eyes (244). Systemic inhibition of VEGF using either systemic ad-sFlt (47, 241, 245) or pharmacological inhibition (246) led to the loss of fenestration and atrophy of the vasculatures of the choroid plexus, choriocapillaris, ciliary body, pancreatic islets, thyroid, adrenal cortex, pituitary, small-intestinal villi, and adipose tissue (243).

The involvement of VEGF in proliferative AMD has led to the development of a number of VEGF blocking therapies. Clinical trials have shown that pegaptanib, an aptamer that blocks VEGF function and was approved for clinical use as Macugen ${ }^{\circledR}$, slows visual loss in the majority of patients with AMD, with some patients showing visual improvement (247). Ranibizumab, a humanized antibody fragment directed against VEGF marketed as Lucentis ${ }^{\circledR}$, was approved for the treatment of neovascular AMD (248) and has been shown to not only stabilize disease progression but also to frequently cause the partial restoration of vision. It is widely believed that the reversal of vision loss is due to the resolution of macular edema, indicating that these therapies are acting primarily as antipermeability agents.

\section{CONCLUSION}

Defective endothelial barrier function is a common feature of many disorders.

Understanding the molecular basis of vascular permeability has led to new therapeutic 
strategies to prevent vascular leakage, which have proven to be successful in a number of preclinical models. The identification of new strategies for reducing permeability and application of existing strategies to an expanding array of abnormal pathologies are the focus of much research. An improved understanding of the molecular and cellular pathways involved in the regulation of vascular permeability will be critical to developing more targeted, efficient, and safe therapies for treating a wide range of human diseases.

This review has provided a greater understanding of how vascular leak impacts the progression of various diseases. Despite significant progress, the field still lacks a comprehensive picture of the mechanisms by which different agonists induce either paracellular or transcellular permeability. Also, signaling pathways and proteins by which different agonists modulate vascular permeability continue to be a complex subject in need of further development. Fully understanding the function of VE-cadherin regulation, for example, would make it possible to design specific agents that can increase or decrease vascular permeability. Further work, therefore, is required to address these key topics in order to design new strategies for reducing permeability. The most important challenge for the future of this field will be to develop suitable treatments to regulate permeability, which may include more sensitive imaging tools to prevent vascular leak or better antipermeability agents to treat different pathophysiological conditions.

\section{LITERATURE CITED}

1. Mehta D, Malik AB. 2006. Signaling mechanisms regulating endothelial permeability. Physiol. Rev86:279-367 [PubMed: 16371600]

2. Folkman J1995. Seminars in Medicine of the Beth Israel Hospital, Boston. Clinical applications of research on angiogenesis. N. Engl. J. Med333:1757-63 [PubMed: 7491141]

3. Carmeliet P2005. Angiogenesis in life, disease and medicine. Nature438:932-36 [PubMed: 16355210]

4. Folkman J2007. Angiogenesis: an organizing principle for drug discovery?Nat. Rev. Drug Discov6:273-86 [PubMed: 17396134]

5. Folkman J2003. Fundamental concepts of the angiogenic process. Curr. Mol. Med3:643-51 [PubMed: 14601638]

6. Goel S, Duda DG, Xu L, Munn LL, Boucher Y, et al.2011. Normalization of the vasculature for treatment of cancer and other diseases. Physiol. Rev91:1071-121 [PubMed: 21742796]

7. Folkman J1971. Tumor angiogenesis: therapeutic implications. N. Engl. J. Med285:1182-86 [PubMed: 4938153]

8. Carmeliet P, Jain RK. 2011. Principles and mechanisms of vessel normalization for cancer and other angiogenic diseases. Nat. Rev. Drug Discov10:417-27 [PubMed: 21629292]

9. Xu K, Cleaver O. 2011. Tubulogenesis during blood vessel formation. Semin. Cell Dev. Biol22:9931004 [PubMed: 21624487]

10. Clark E, Clark EL. 1935. Observations on changes in blood vascular endothelium in the living animal. Am. J. Anat57:384-438

11. Abell R1946. The permeability of blood capillary sprouts and newly formed blood capillaries as compared to that of older capillaries. Am. J. Physiol147:231-41

12. Schoefl GI. 1963. Studies on inflammation. II. Growing capillaries: their structure and permeability. Virchows Arch. Pathol. Anat. Physiol. Klin. Med337:97-141 [PubMed: 14098690]

13. Seymour LW. 1992. Passive tumor targeting of soluble macromolecules and drug conjugates. Crit. Rev. Ther. Drug Carrier Syst9:135-87 [PubMed: 1386002]

14. Aird WC. 2007. Phenotypic heterogeneity of the endothelium: I. Structure, function, and mechanisms. Circ. Res100:158-73 [PubMed: 17272818] 
15. Dempsey EW, Wislocki GB. 1955. An electron microscopic study of the blood-brain barrier in the rat, employing silver nitrate as a vital stain. J. Biophys. Biochem. Cytol1:245-56 [PubMed: 13242590]

16. Schackert G, Simmons RD, Buzbee TM, Hume DA, Fidler IJ. 1988. Macrophage infiltration into experimental brain metastases: occurrence through an intact blood-brain barrier. J. Natl. Cancer Inst80:1027-34 [PubMed: 3261801]

17. Feng D, Nagy JA, Pyne K, Hammel I, Dvorak HF, Dvorak AM. 1999. Pathways of macromolecular extravasation across microvascular endothelium in response to VPF/VEGF and other vasoactive mediators. Microcirculation6:23-44 [PubMed: 10100187]

18. Feng D, Nagy JA, Hipp J, Dvorak HF, Dvorak AM. 1996. Vesiculo-vacuolar organelles and the regulation of venule permeability to macromolecules by vascular permeability factor, histamine, and serotonin. J. Exp. Med183:1981-86 [PubMed: 8642308]

19. Schubert W, Frank PG, Woodman SE, Hyogo H, Cohen DE, et al.2002. Microvascular hyperpermeability in caveolin-1 (-/-) knock-out mice. Treatment with a specific nitric-oxide synthase inhibitor, L-NAME, restores normal microvascular permeability in Cav-1 null mice. J. Biol. Chem277:40091-98 [PubMed: 12167625]

20. Dejana E2004. Endothelial cell-cell junctions: happy together. Nat. Rev. Mol. Cell Biol5:261-70 [PubMed: 15071551]

21. Carmeliet P1999. Developmental biology. Controlling the cellular brakes. Nature401:657-58 [PubMed: 10537101]

22. Crosby CV, Fleming PA, Argraves WS, Corada M, Zanetta L, et al.2005. VE-cadherin is not required for the formation of nascent blood vessels but acts to prevent their disassembly. Blood105:2771-76 [PubMed: 15604224]

23. Corada M, Mariotti M, Thurston G, Smith K, Kunkel R, et al.1999. Vascular endothelial-cadherin is an important determinant of microvascular integrity in vivo. PNAS96:9815-20 [PubMed: 10449777]

24. Weber C, Fraemohs L, Dejana E. 2007. The role of junctional adhesion molecules in vascular inflammation. Nat. Rev. Immunol7:467-77 [PubMed: 17525755]

25. Tsukita S, Furuse M, Itoh M. 2001. Multifunctional strands in tight junctions. Nat. Rev. Mol. Cell Biol2:285-93 [PubMed: 11283726]

26. Nitta T, Hata M, Gotoh S, Seo Y, Sasaki H, et al.2003. Size-selective loosening of the blood-brain barrier in claudin-5-deficient mice. J. Cell Biol161:653-60 [PubMed: 12743111]

27. Kluger MS, Clark PR, Tellides G, Gerke V, Pober JS. 2013. Claudin-5 controls intercellular barriers of human dermal microvascular but not human umbilical vein endothelial cells. Arterioscler. Thromb. Vasc. Biol33:489-500 [PubMed: 23288152]

28. Geiger B, Spatz JP, Bershadsky AD. 2009. Environmental sensing through focal adhesions. Nat. Rev. Mol. Cell Biol10:21-33 [PubMed: 19197329]

29. Huveneers S, Oldenburg J, Spanjaard E, van der Krogt G, Grigoriev I, et al.2012. Vinculin associates with endothelial VE-cadherin junctions to control force-dependent remodeling. J. Cell Biol196:641-52 [PubMed: 22391038]

30. Chen XL, Nam JO, Jean C, Lawson C, Walsh CT, et al.2012. VEGF-induced vascular permeability is mediated by FAK. Dev. Cell22:146-57 [PubMed: 22264731]

31. Gaengel K, Genove G, Armulik A, Betsholtz C. 2009. Endothelial-mural cell signaling in vascular development and angiogenesis. Arterioscler. Thromb. Vasc. Biol29:630-38 [PubMed: 19164813]

32. Hirschi KK, Burt JM, Hirschi KD, Dai C. 2003. Gap junction communication mediates transforming growth factor- $\beta$ activation and endothelial-induced mural cell differentiation. Circ. Res93:429-37 [PubMed: 12919949]

33. Palade GE. 1953. Fine structure of blood capillaries. J. Appl. Phys24.1: 1424-36

34. Dvorak AM. 2007. Endothelial biomedicine. New York: Cambridge Univ. Press

35. Chang SH, Feng D, Nagy JA, Sciuto TE, Dvorak AM, Dvorak HF. 2009. Vascular permeability and pathological angiogenesis in caveolin-1-null mice. Am. J. Pathol175:1768-76 [PubMed: 19729487] 
36. Majno G, Palade GE, Schoefl GI. 1961. Studies on inflammation. II. The site of action of histamine and serotonin along the vascular tree: a topographic study. J. Biophys. Biochem. Cytol11:607-26 [PubMed: 14468625]

37. Kohn S, Nagy JA, Dvorak HF, Dvorak AM. 1992. Pathways of macromolecular tracer transport across venules and small veins. Structural basis for the hyperpermeability of tumor blood vessels. Lab. Investig. J. Tech. Methods Pathol67:596-607

38. Dvorak AM, Kohn S, Morgan ES, Fox P, Nagy JA, Dvorak HF. 1996. The vesiculo-vacuolar organelle (VVO): a distinct endothelial cell structure that provides a transcellular pathway for macromolecular extravasation. J. Leukoc. Biol59:100-15 [PubMed: 8558058]

39. Nagy JA, Dvorak AM, Dvorak HF. 2007. VEGF-A and the induction of pathological angiogenesis. Annu. Rev. Pathol2:251-75 [PubMed: 18039100]

40. Nagy JA, Chang SH, Shih SC, Dvorak AM, Dvorak HF. 2010. Heterogeneity of the tumor vasculature. Semin. Thromb. Hemost36:321-31 [PubMed: 20490982]

41. Chang SH, Kanasaki K, Gocheva V, Blum G, Harper J, et al.2009. VEGF-A induces angiogenesis by perturbing the cathepsin-cysteine protease inhibitor balance in venules, causing basement membrane degradation and mother vessel formation. Cancer Res. 69:4537-44 [PubMed: 19435903]

42. Valdez CN, Arboleda-Velasquez JF, Amarnani DS, Kim LA, D’ Amore PA. 2014. Retinal microangio-pathy in a mouse model of inducible mural cell loss. Am. J. Pathol184:2618-26 [PubMed: 25092275]

43. Senger DR, Galli SJ, Dvorak AM, Perruzzi CA, Harvey VS, Dvorak HF. 1983. Tumor cells secrete a vascular permeability factor that promotes accumulation of ascites fluid. Science219:983-85 [PubMed: 6823562]

44. Ferrara N, Henzel WJ. 1989. Pituitary follicular cells secrete a novel heparin-binding growth factor specific for vascular endothelial cells. Biochem. Biophys. Res. Commun161:851-58 [PubMed: 2735925]

45. Roberts WG, Palade GE. 1995. Increased microvascular permeability and endothelial fenestration induced by vascular endothelial growth factor. J. Cell Sci108(Pt. 6):2369-79 [PubMed: 7673356]

46. dela Paz NG, D’Amore PA. 2009. Arterial versus venous endothelial cells. Cell Tissue Res. 335:516 [PubMed: 18972135]

47. Maharaj AS, Walshe TE, Saint-Geniez M, Venkatesha S, Maldonado AE, et al.2008. VEGF and TGF- $\beta$ are required for the maintenance of the choroid plexus and ependyma. J. Exp. Med205:491-501 [PubMed: 18268040]

48. D'Amore PA. 2007. Vascular endothelial cell growth factor-A: not just for endothelial cells anymore. Am. J. Pathol171:14-18 [PubMed: 17591949]

49. Houck KA, Ferrara N, Winer J, Cachianes G, Li B, Leung DW. 1991. The vascular endothelial growth factor family: identification of a fourth molecular species and characterization of alternative splicing of RNA. Mol. Endocrinol5:1806-14 [PubMed: 1791831]

50. Jingjing L, Xue Y, Agarwal N, Roque RS. 1999. Human Muller cells express VEGF183, a novel spliced variant of vascular endothelial growth factor. Investig. Ophthalmol. Vis. Sci40:752-59 [PubMed: 10067980]

51. Tischer E, Mitchell R, Hartman T, Silva M, Gospodarowicz D, et al.1991. The human gene for vascular endothelial growth factor. Multiple protein forms are encoded through alternative exon splicing. J. Biol. Chem266:11947-54 [PubMed: 1711045]

52. Whittle C, Gillespie K, Harrison R, Mathieson PW, Harper SJ. 1999. Heterogeneous vascular endothelial growth factor (VEGF) isoform mRNA and receptor mRNA expression in human glomeruli, and the identification of VEGF148 mRNA, a novel truncated splice variant. Clin. Sci97:303-12

53. de Vries C, Escobedo JA, Ueno H, Houck K, Ferrara N, Williams LT. 1992. The fms-like tyrosine kinase, a receptor for vascular endothelial growth factor. Science255:989-91 [PubMed: 1312256]

54. Terman BI, Dougher-Vermazen M, Carrion ME, Dimitrov D, Armellino DC, et al.1992. Identification of the KDR tyrosine kinase as a receptor for vascular endothelial cell growth factor. Biochem. Biophys. Res. Commun187:1579-86 [PubMed: 1417831] 
55. Pajusola K, Aprelikova O, Korhonen J, Kaipainen A, Pertovaara L, et al.1992. FLT4 receptor tyrosine kinase contains seven immunoglobulin-like loops and is expressed in multiple human tissues and cell lines. Cancer Res. 52:5738-43 [PubMed: 1327515]

56. Soker S, Takashima S, Miao HQ, Neufeld G, Klagsbrun M. 1998. Neuropilin-1 is expressed by endothelial and tumor cells as an isoform-specific receptor for vascular endothelial growth factor. Cel192:735-45 [PubMed: 9529250]

57. Olsson AK, Dimberg A, Kreuger J, Claesson-Welsh L. 2006. VEGF receptor signalling - in control of vascular function. Nat. Rev. Mol. Cell Biol7:359-71 [PubMed: 16633338]

58. Wheeler-Jones C, Abu-Ghazaleh R, Cospedal R, Houliston RA, Martin J, Zachary I. 1997. Vascular endothelial growth factor stimulates prostacyclin production and activation of cytosolic phospholipase A2 in endothelial cells via p42/p44 mitogen-activated protein kinase. FEBS Lett. 420:28-32 [PubMed: 9450544]

59. Gerber HP, Dixit V, Ferrara N. 1998. Vascular endothelial growth factor induces expression of the antiapoptotic proteins Bcl-2 and A1 in vascular endothelial cells. J. Biol. Chem273:13313-16 [PubMed: 9582377]

60. Glass CA, Harper SJ, Bates DO. 2006. The anti-angiogenic VEGF isoform VEGF165b transiently increases hydraulic conductivity, probably through VEGF receptor 1 in vivo. J. Physiol572:243-57 [PubMed: 16423853]

61. Ku DD, Zaleski JK, Liu S, Brock TA. 1993. Vascular endothelial growth factor induces EDRFdependent relaxation in coronary arteries. Am. J. Physiol265:H586-92 [PubMed: 8368362]

62. Greenberg JI, Shields DJ, Barillas SG, Acevedo LM, Murphy E, et al.2008. A role for VEGF as a negative regulator of pericyte function and vessel maturation. Nature456:809-13 [PubMed: 18997771]

63. Unemori EN, Ferrara N, Bauer EA, Amento EP. 1992. Vascular endothelial growth factor induces interstitial collagenase expression in human endothelial cells. J. Cell. Physiol153:557-62 [PubMed: 1447317]

64. Yang R, Thomas GR, Bunting S, Ko A, Ferrara N, et al.1996. Effects of vascular endothelial growth factor on hemodynamics and cardiac performance. J. Cardiovasc. Pharmacol27:838-44 [PubMed: 8761851]

65. Vajanto I, Rissanen TT, Rutanen J, Hiltunen MO, Tuomisto TT, et al.2002. Evaluation of angiogenesis and side effects in ischemic rabbit hindlimbs after intramuscular injection of adenoviral vectors encoding VEGF and LacZ. J. Gene Med4:371-80 [PubMed: 12124979]

66. Wang WY, Whittles CE, Harper SJ, Bates DO. 2004. An adenovirus-mediated gene-transfer model of angiogenesis in rat mesentery. Microcirculation11:361-75 [PubMed: 15280075]

67. Hudson N, Powner MB, Sarker MH, Burgoyne T, Campbell M, et al.2014. Differential apicobasal VEGF signaling at vascular blood-neural barriers. Dev. Cell30:541-52 [PubMed: 25175707]

68. Tran J, Rak J, Sheehan C, Saibil SD, LaCasse E, et al.1999. Marked induction of the IAP antiapoptotic proteins survivin and XIAP by VEGF in vascular endothelial cells. Biochem. Biophys. Res. Commun264:781-88 [PubMed: 10544009]

69. Dimmeler S, Dernbach E, Zeiher AM. 2000. Phosphorylation of the endothelial nitric oxide synthase at Ser-1177 is required for VEGF-induced endothelial cell migration. FEBS Lett. 477:258-62 [PubMed: 10908731]

70. Seymour LW, Shoaibi MA, Martin A, Ahmed A, Elvin P, et al.1996. Vascular endothelial growth factor stimulates protein kinase C-dependent phospholipase D activity in endothelial cells. Lab. Investig75:427-37 [PubMed: 8804365]

71. Soga N, Connolly JO, Chellaiah M, Kawamura J, Hruska KA. 2001. Rac regulates vascular endothelial growth factor stimulated motility. Cell Commun. Adhes8:1-13 [PubMed: 11775025]

72. Garrett TA, Van Buul JD, Burridge K. 2007. VEGF-induced Rac1 activation in endothelial cells is regulated by the guanine nucleotide exchange factor Vav2. Exp. Cell Res313:3285-97 [PubMed: 17686471]

73. Abedi H, Zachary I. 1997. Vascular endothelial growth factor stimulates tyrosine phosphorylation and recruitment to new focal adhesions of focal adhesion kinase and paxillin in endothelial cells. J. Biol. Chem272:15442-51 [PubMed: 9182576] 
74. Mahabeleshwar GH, Feng W, Reddy K, Plow EF, Byzova TV. 2007. Mechanisms of integrinvascular endothelial growth factor receptor cross-activation in angiogenesis. Circ. Res101:570-80 [PubMed: 17641225]

75. Tugues S, Honjo S, Konig C, Padhan N, Kroon J, et al.2013. Tetraspanin CD63 promotes vascular endothelial growth factor receptor 2- $\beta 1$ integrin complex formation, thereby regulating activation and downstream signaling in endothelial cells in vitro and in vivo. J. Biol. Chem288:19060-71 [PubMed: 23632027]

76. Bhattacharya R, Gonzalez AM, Debiase PJ, Trejo HE, Goldman RD, et al.2009. Recruitment of vimentin to the cell surface by $\beta 3$ integrin and plectin mediates adhesion strength. J. Cell. Sci122:1390-400 [PubMed: 19366731]

77. Yamaoka-Tojo M, Tojo T, Kim HW, Hilenski L, Patrushev NA, et al.2006. IQGAP1 mediates VE-cadherin-based cell-cell contacts and VEGF signaling at adherence junctions linked to angiogenesis. Arterioscler. Thromb. Vasc. Biol26:1991-97 [PubMed: 16763158]

78. Rousseau S, Houle F, Landry J, Huote J. 1997. p38 MAP kinase activation by vascular endothelial growth factor mediates actin reorganization and cell migration in human endothelial cells. Oncogene15:2169-77 [PubMed: 9393975]

79. Rousseau S, Houle F, Kotanides H, Witte L, Waltenberger J, et al.2000. Vascular endothelial growth factor (VEGF)-driven actin-based motility is mediated by VEGFR2 and requires concerted activation of stress-activated protein kinase 2 (SAPK2/p38) and geldanamycin-sensitive phosphorylation of focal adhesion kinase. J Biol. Chem275:10661-72 [PubMed: 10744763]

80. Matsumoto T, Bohman S, Dixelius J, Berge T, Dimberg A, et al.2005. VEGF receptor-2 Y951 signaling and a role for the adapter molecule TSAd in tumor angiogenesis. EMBO J. 24:2342-53 [PubMed: 15962004]

81. Lamalice L, Houle F, Huot J. 2006. Phosphorylation of Tyr ${ }^{1214}$ within VEGFR-2 triggers the recruitment of Nck and activation of Fyn leading to SAPK2/p38 activation and endothelial cell migration in response to VEGF. J. Biol. Chem281:34009-20 [PubMed: 16966330]

82. Cain RJ, Ridley AJ. 2009. Phosphoinositide 3-kinases in cell migration. Biol. Cell101:13-29 [PubMed: 19055486]

83. Shizukuda Y, Tang S, Yokota R, Ware A. 1999. Vascular endothelial growth factor-induced endothelial cell migration and proliferation depend on a nitric oxide-mediated decrease in protein kinase CSactivity. Circ. Res85:247-56 [PubMed: 10436167]

84. Holmqvist K, Cross MJ, Rolny C, Hagerkvist R, Rahimi N, et al.2004. The adaptor protein Shb binds to tyrosine 1175 in vascular endothelial growth factor (VEGF) receptor-2 and regulates VEGF-dependent cellular migration. J. Biol. Chem279:22267-75 [PubMed: 15026417]

85. Zeng H, Zhao D, Yang S, Datta K, Mukhopadhyay D. 2003. Heterotrimeric Gaq/Ga 11 proteins function upstream of vascular endothelial growth factor (VEGF) receptor-2 (KDR) phosphorylation in vascular permeability factor/VEGF signaling. J. Biol. Chem278:20738-45 [PubMed: 12670961]

86. Wellner M, Maasch C, Kupprion C, Lindschau C, Luft FC, Haller H. 1999. The proliferative effect of vascular endothelial growth factor requires protein kinase $\mathrm{C}-\mathrm{a}$ and protein kinase $\mathrm{C}-\boldsymbol{\zeta}$. Arterioscler. Thromb. Vasc. Biol19:178-85 [PubMed: 9888881]

87. Soldi R, Mitola S, Strasly M, Defilippi P, Tarone G, Bussolino F. 1999. Role of $a_{v} b_{3}$ integrin in the activation of vascular endothelial growth factor receptor-2. EMBO J. 18:882-92 [PubMed: 10022831]

88. Hood J, Granger HJ. 1998. Protein kinase G mediates vascular endothelial growth factor-induced Raf-1 activation and proliferation in human endothelial cells. J. Biol. Chem273:23504-8 [PubMed: 9722588]

89. Papapetropoulos A, Garcia-Gardena G, Madri J, Sessa W. 1997. Nitric oxide production contributes to the angiogenic properties of vascular endothelial growth factor in human endothelial cells. J. Clin. Investig100:3131-39 [PubMed: 9399960]

90. Nakamura Y, Patrushev N, Inomata J, Mehta D, Urao N, et al.2008. Role of protein tyrosine phosphatase 1B in vascular endothelial growth factor signaling and cell-cell adhesions in endothelial cells. Circ. Res102:1182-91 [PubMed: 18451337] 
91. Wong C, Jin ZG. 2005. Protein kinase C-dependent protein kinase D activation modulates ERK signal pathway and endothelial cell proliferation by vascular endothelial growth factor. J. Biol. Chem280:33262-69 [PubMed: 16006559]

92. Staker S, Vitali A, Caesar C, Domagala T, Groenen LC, et al.1999. A mutant form of vascular endothelial growth factor (VEGF) that lacks VEGF receptor-2 activation retains the ability to induce vascular permeability. J. Biol. Chem274:34884-92 [PubMed: 10574962]

93. Antonetti DA, Barber AJ, Hollinger LA, Wolpert EB, Gardner TW. 1999. Vascular endothelial growth factor induces rapid phosphorylation of tight junction proteins occludin and zonula occluden 1: a potential mechanism for vascular permeability in diabetic retinopathy and tumors. J. Biol. Chem274:23463-67 [PubMed: 10438525]

94. Murohara T, Horowitz JR, Silver M, Tsurumi Y, Chen D, et al.1998. Vascular endothelial growth factor/vascular permeability factor enhances vascular permeability via nitric oxide and prostacyclin. Circulation97:99-107 [PubMed: 9443437]

95. Fischer S, Clauss M, Wiesnet M, Renz D, Schaper W, Karliczek G. 1999. Hypoxia induces permeability in brain microvessel endothelial cells via VEGF and NO. Am. J. Physiol276:C81220 [PubMed: 10199811]

96. Wu HM, Yuan Y, Zawieja DC, Tinsley J, Granger H. 1999. Role of phospholipase C, protein kinase C, and calcium in VEGF-induced venular hyperpermeability. Am. J. Physiol276:H535-42 [PubMed: 9950855]

97. Senger D, Claffey K, Benes J, Perruzzi C, Sergiou A, Detmar M. 1997. Angiogenesis promoted by vascular endothelial growth factor: regulation through $\mathrm{a}_{1} \mathrm{~b}_{1}$ and $\mathrm{a}_{2} \mathrm{~b}_{1}$ integrins. PNAS94:13612-17 [PubMed: 9391074]

98. Wu LW, Mayo LD, Dunbar JD, Kessler KM, Baerwald MR, et al.2000. Utilization of distinct signaling pathways by receptors for vascular endothelial growth factor and other mitogens in the induction of endothelial cell proliferation. J. Biol. Chem275:5096-103 [PubMed: 10671553]

99. Doanes AM, Hegland DD, Sethi R, Kovesdi I, Bruder JT, Finkel T. 1999. VEGF stimulates MAPK through a pathway that is unique for receptor tyrosine kinases. Biochem. Biophys. Res. Commun255:545-48 [PubMed: 10049745]

100. Pedram A, Razandi M, Levin ER. 1998. Extracellular signal-regulated protein kinase/Jun kinase cross-talk underlies vascular endothelial cell growth factor-induced endothelial cell proliferation. J. Biol. Chem273:26722-28 [PubMed: 9756915]

101. Xia P, Aiello LP, Ishii H, Jiang ZY, Park DJ, et al.1996. Characterization of vascular endothelial growth factor's effect on the activation of protein kinase C, its isoforms, and endothelial cell growth. J. Clin. Investig98:2018-26 [PubMed: 8903320]

102. Takahashi T, Ueno H, Shibuya M. 1999. VEGF activates protein kinase C-dependent, but Rasindependent Raf-MEK-MAP kinase pathway for DNA synthesis in primary endothelial cells. Oncogene18:2221-30 [PubMed: 10327068]

103. Takahashi T, Yamaguchi S, Chida K, Shibuya M. 2001. A single autophosphorylation site on KDR/Flk-1 is essential for VEGF-A-dependent activation of PLC- $\gamma$ and DNA synthesis in vascular endothelial cells. EMBO J. 20:2768-78 [PubMed: 11387210]

104. Kroll J, Waltenberger J. 1997. The vascular endothelial growth factor receptor KDR activates multiple signal transduction pathways in porcine aortic endothelial cells. J. Biol. Chem272:32521-27 [PubMed: 9405464]

105. Bouloumie A, Schini-Kerth V, Busse R. 1999. Vascular endothelial growth factor up-regulates nitric oxide synthase expression in endothelial cells. Cardiovasc. Res41:773-80 [PubMed: 10435050]

106. Parenti A, Morbidelli L, Cui XL, Douglas JG, Hood JD, et al.1998. Nitric oxide is an upstream signal of vascular endothelial growth factor-induced extracellular signal-regulated kinase $1 / 2$ activation in postcapillary endothelium. J. Biol. Chem273:4220-26 [PubMed: 9461619]

107. Dimmeler S, Fleming I, Fisslthaler B, Hermann C, Busse R, Zeiher AM. 1999. Activation of nitric oxide synthase in endothelial cells by Akt-dependent phosphorylation. Nature399:601-5 [PubMed: 10376603] 
108. Fulton D, Gratton JP, McCabe TJ, Fontana J, Fujio Y, et al.1999. Regulation of endotheliumderived nitric oxide production by the protein kinase Akt. Nature399:597-601 [PubMed: 10376602]

109. He H, Venema VJ, Gu X, Venema RC, Marrero MB, Caldwell RB. 1999. Vascular endothelial growth factor signals endothelial cell production of nitric oxide and prostacyclin through Flk-1/KDR activation of c-Src. J. Biol. Chem274:25130-35 [PubMed: 10455194]

110. Clauss M, Weich H, Breier G, Knies U, Rocki W, et al.1996. The vascular endothelial growth factor receptor Flt-1 mediates biological activities. Implications for a functional role of placenta growth factor in monocyte activation and chemotaxis. J. Biol. Chem271:17629-34 [PubMed: 8663424]

111. Oh H, Tagaki H, Suzuma K, Otani A, Matsumura M, Honda Y. 1999. Hypoxia and vascular endothelial growth factor selectively upregulate angiopoietin-2 in bovine microvascular endothelial cells. J. Biol. Chem274:15732-39 [PubMed: 10336473]

112. Shen B-Q, Lee DY, Zioncheck TF. 1999. Vascular endothelial growth factor governs endothelial nitric-oxide synthase expression via a KDR/Flk-1 receptor and protein kinase $\mathrm{C}$ signaling pathway. J. Biol. Chem274:33057-63 [PubMed: 10551875]

113. Cunningham SA, Tran TM, Arrate MP, Bjercke R, Brock TA. 1999. KDR activation is crucial for VEGF-mediated Ca mobilization in human umbilical vein endothelial cells. Am. J. Physiol276:C176-81 [PubMed: 9886933]

114. Kroll J, Waltenberger J. 1999. A novel function of the vascular endothelial growth factor receptor-2 (KDR): rapid release of nitric oxide in response to VEGF-A stimulation in endothelial cells. Biochem. Biophys. Res. Commun265:636-39 [PubMed: 10600473]

115. Dejana E, Spagnuolo R, Bazzoni G. 2001. Interendothelial junctions and their role in the control of angiogenesis, vascular permeability and leukocyte transmigration. Thromb. Haemost86:30815 [PubMed: 11487019]

116. Eliceiri BP, Paul R, Schwartzberg PL, Hood JD, Leng J, Cheresh DA. 1999. Selective requirement for Src kinases during VEGF-induced angiogenesis and vascular permeability. Mol. Cell4:91524 [PubMed: 10635317]

117. Lampugnani MG, Orsenigo F, Gagliani MC, Tacchetti C, Dejana E. 2006. Vascular endothelial cadherin controls VEGFR-2 internalization and signaling from intracellular compartments. J. Cell Biol174:593-604 [PubMed: 16893970]

118. Weis S, Shintani S, Weber A, Kirchmair R, Wood M, et al.2004. Src blockade stabilizes a Flk/cadherin complex, reducing edema and tissue injury following myocardial infarction. J. Clin. Investig113:885-94 [PubMed: 15067321]

119. Gavard J, Gutkind JS. 2006. VEGF controls endothelial-cell permeability by promoting the $\beta$-arrestin-dependent endocytosis of VE-cadherin. Nat. Cell Biol8:1223-34 [PubMed: 17060906]

120. Hebda JK, Leclair HM, Azzi S, Roussel C, Scott MG, et al.2013. The C-terminus region of $\beta$-arrestin1 modulates VE-cadherin expression and endothelial cell permeability. Cell Commun. Signal.: CCS11:37 [PubMed: 23714586]

121. Franco CA, Mericskay M, Parlakian A, Gary-Bobo G, Gao-Li J, et al.2008. Serum response factor is required for sprouting angiogenesis and vascular integrity. Dev. Cell15:448-61 [PubMed: 18804439]

122. Potter MD, Barbero S, Cheresh DA. 2005. Tyrosine phosphorylation of VE-cadherin prevents binding of p120- and $\beta$-catenin and maintains the cellular mesenchymal state. J. Biol. Chem280:31906-12 [PubMed: 16027153]

123. Orsenigo D, Giampietro C, Ferrari A, Corada M, Galaup A, et al.2012. Phosphorylation of VE-cadherin is modulated by haemodynamic forces and contributes to the regulation of vascular permeability in vivo. Nat. Commun3:1208 [PubMed: 23169049]

124. Wallez Y, Cand F, Cruzalegui F, Wernstedt C, Souchelnytskyi S, et al.2007. Src kinase phosphorylates vascular endothelial-cadherin in response to vascular endothelial growth factor: identification of tyrosine 685 as the unique target site. Oncogene26:1067-77 [PubMed: 16909109] 
125. Turowski P, Martinelli R, Crawford R, Wateridge D, Papageorgiou AP, et al.2008. Phosphorylation of vascular endothelial cadherin controls lymphocyte emigration. J. Cell Sci121:29-37 [PubMed: 18096689]

126. Spring K, Chabot C, Langlois S, Lapointe L, Trinh NT, et al.2012. Tyrosine phosphorylation of DEP-1/CD148 as a mechanism controlling Src kinase activation, endothelial cell permeability, invasion, invasion, and capillary formation. Blood120:2745-56 [PubMed: 22898603]

127. Schulte D, Kuppers V, Dartsch N, Broermann A, Li H, et al.2011. Stabilizing the VE-cadherincatenin complex blocks leukocyte extravasation and vascular permeability. EMBO J. 30:4157-70 [PubMed: 21857650]

128. Gavard J, Patel V, Gutkind JS. 2008. Angiopoietin-1 prevents VEGF-induced endothelial permeability by sequestering Src through mDia. Dev. Cell14:25-36 [PubMed: 18194650]

129. Eliceiri BP, Schwartzberg PL, Hood JD, Leng J, Cheresh DA. 1999. Selective requirement for Src kinases during VEGF-induced angiogenesis and vascular permeability. Mol. Cell4:915-24 [PubMed: 10635317]

130. Adam AP, Sharenko AL, Pumiglia K, Vincent PA. 2010. Src-induced tyrosine phosphorylation of VE-cadherin is not sufficient to decrease barrier function of endothelial monolayers. J. Biol. Chem285:7045-55 [PubMed: 20048167]

131. Zhao X, Peng X, Shaogang S, Park AYJ, Guan JL. 2010. Role of kinase-independent and -dependent functions of FAK in endothelial cell survival and barrier function during embryonic development. J. Cell Biol189:955-65 [PubMed: 20530207]

132. Wojciak-Stothard B, Ridley AJ. 2002. Rho GTPases and the regulation of endothelial permeability. Vasc. Pharmacol39:187-99

133. Wójciak-Stothard B, Potempa S, Eichholtz T, Ridley AJ. 2001. Rho and Rac but not Cdc42 regulate endothelial cell permeability. J. Cell Sci114:1343-55 [PubMed: 11257000]

134. Gaengel K, Niaudet C, Hagikura K, Siemsen BL, Muhl L, et al.2012. The sphingosine-1phosphate receptor S1PR1 restricts sprouting angiogenesis by regulating the interplay between VE-cadherin and VEGFR2. Dev. Cell23:587-99 [PubMed: 22975327]

135. Xiao K, Garner J, Buckley KM, Vincent PA, Chiasson CM, et al.2005. p120-catenin regulates clathrin-dependent endocytosis of VE-cadherin. Mol. Biol. Cell16:5141-51 [PubMed: 16120645]

136. Vandenbroucke St Amant E, Tauseef M, Vogel SM, Gao XP, et al.2012. PKCa activation of p120-catenin serine 879 phospho-switch disassembles VE-cadherin junctions and disrupts vascular integrity. Circ. Res111:739-49 [PubMed: 22798526]

137. Li R, Ren M, Chen N, Luo M, Zhang Z, Wu J. 2012. Vitronectin increases vascular permeability by promoting VE-cadherin internalization at cell junctions. PLOS ONE7:e37195 [PubMed: 22606350]

138. Yoshioka K, Yoshida K, Cui H, Wakayama T, Takuwa N, et al.2012. Endothelial PI3K-C2a, a class II PI3K, has an essential role in angiogenesis and vascular barrier function. Nat. Med18:1560-69 [PubMed: 22983395]

139. Chiasson CM, Wittich KB, Vincent PA, Faundez V, Kowalczyk AP. 2009. p120-catenin inhibits VE-cadherin internalization through a Rho-independent mechanism. Mol. Biol. Cell20:1970-80 [PubMed: 19211843]

140. Gavard J, Hou X, Qu Y, Masedunskas A, Martin D, et al.2009. A role for a CXCR2/ phosphatidylinositol 3-kinase $\gamma$ signaling axis in acute and chronic vascular permeability. Mol. Cell. Biol29:2469-80 [PubMed: 19255141]

141. Cain RJ, Vanhaesebroeck B, Ridley AJ. 2010. The PI3K p110a isoform regulates endothelial adherens junctions via Pyk2 and Rac1. J. Cell Biol188:863-76 [PubMed: 20308428]

142. Jones CA, London NR, Chen H, Park KW, Sauvaget D, et al.2008. Robo4 stabilizes the vascular network by inhibiting pathologic angiogenesis and endothelial hyperpermeability. Nat. Med14:448-53 [PubMed: 18345009]

143. Cowan CE, Kohler EE, Dugan TA, Mirza MK, Malik AB, et al.2010. Kruppel-like factor-4 transcriptionally regulates VE-cadherin expression and endothelial barrier function. Circ. Res 107:959-66 [PubMed: 20724706] 
144. Taddei A, Giampietro C, Conti A, Orsenigo F, Breviario F, et al.2008. Endothelial adherens junctions control tight junctions by VE-cadherin-mediated upregulation of claudin-5. Nat. Cell Biol10:923-34 [PubMed: 18604199]

145. Liebner S, Corada M, Bangsow T, Babbage J, Taddei A, et al.2008. Wnt/ $\beta$-catenin signaling controls development of the blood-brain barrier. J. Cell Biol183:409-17 [PubMed: 18955553]

146. Oas RG, Xiao K, Summers S, Wittich KB, Chiasson CM, et al.2010. p120-Catenin is required for mouse vascular development. Circ. Res106:941-51 [PubMed: 20110533]

147. Young JA, Ting KK, Li J, Moller T, Dunn L, et al.2013. Regulation of vascular leak and recovery from ischemic injury by general and VE-cadherin-restricted miRNA antagonists of miR-27. Blood122:2911-19 [PubMed: 24009229]

148. Muramatsu F, Kidoya H, Naito H, Sakimoto S, Takakura N. 2013. microRNA-125b inhibits tube formation of blood vessels through translational suppression of VE-cadherin. Oncogene 32:41421 [PubMed: 22391569]

149. Lalwani MK, Sharma M, Singh AR, Chauhan RK, Patowary A, et al.2012. Reverse genetics screen in zebrafish identifies a role of miR-142a-3p in vascular development and integrity. PLOS ONE7:e52588 [PubMed: 23285103]

150. Hla T2004. Physiological and pathological actions of sphingosine 1-phosphate. Semin. Cell Dev. Biol15:513-20 [PubMed: 15271296]

151. Sanchez T, Skoura A, Wu MT, Casserly B, Harrington EO, Hla T. 2007. Induction of vascular permeability by the sphingosine-1-phosphate receptor-2 (S1P2R) and its downstream effectors ROCK and PTEN. Arterioscler. Thromb. Vasc. Biol27:1312-18 [PubMed: 17431187]

152. Zhao J, Singleton PA, Brown ME, Dudek SM, Garcia JG. 2009. Phosphotyrosine protein dynamics in cell membrane rafts of sphingosine-1-phosphate-stimulated human endothelium: role in barrier enhancement. Cell. Signal21:1945-60 [PubMed: 19755153]

153. Belvitch P, Dudek SM. 2012. Role of FAK in S1P-regulated endothelial permeability. Microvasc. Res83:22-30 [PubMed: 21925517]

154. Mullershausen F, Craveiro LM, Shin Y, Cortes-Cros M, Bassilana F, et al.2007. Phosphorylated FTY720 promotes astrocyte migration through sphingosine-1-phosphate receptors. J. Neurochem102:1161-66

155. Pham THM, Okada T, Matloubian M, Lo C, Cyster JG. 2008. S1P1 receptor signaling overrides retention mediated by Gai-coupled receptors to promote T cell egress. Immunity28:122-33 [PubMed: 18164221]

156. Landeen LK, Dederko DA, Kondo CS, Hu BS, Aroonsakool N, et al.2008. Mechanisms of the negative inotropic effects of sphingosine-1-phosphate on adult mouse ventricular myocytes. Am. J. Physiol. Heart. Circ. Physiol294:H736-49 [PubMed: 18024550]

157. Nakajima N, Cavalli AL, Biral D, Glembotski CC, McDonough PM, et al.2000. Expression and characterization of Edg-1 receptors in rat cardiomyocytes: calcium deregulation in response to sphingosine 1-phosphate. Eur. J. Biochem267:5679-86 [PubMed: 10971577]

158. Jung B, Obinata H, Galvani S, Mendelson K, Ding B, et al.2012. Flow-regulated endothelial S1P receptor-1 signaling sustains vascular development. Dev. Cell23:600-10 [PubMed: 22975328]

159. Igarashi J, Erwin PA, Dantas APV, Chen H, Michel T. 2003. VEGF induces S1P1 receptors in endothelial cells: implications for cross-talk between sphingolipid and growth factor receptors. PNAS 100:10664-69 [PubMed: 12963813]

160. Paik JH, Chae S, Lee MJ, Thangada S, Hla T. 2001. Sphingosine 1-phosphate-induced endothelial cell migration requires the expression of EDG-1 and EDG-3 receptors and Rho-dependent activation of $\alpha_{v} \beta_{3}$ - and $\beta_{1}$-containing integrins. J. Biol. Chem276:11830-37 [PubMed: 11150298]

161. Benaud C, Oberst M, Hobson JP, Spiegel S, Dickson RB, Lin CY. 2002. Sphingosine 1phosphate, present in serum-derived lipoproteins, activates matriptase. J. Biol. Chem277:1053946 [PubMed: 11792696]

162. Feistritzer C, Riewald M. 2005. Endothelial barrier protection by activated protein $C$ through PAR1-dependent sphingosine 1-phosphate receptor-1 crossactivation. Blood105:3178-84 [PubMed: 15626732] 
163. Mizuguishi K, Yamashita T, Olivera A, Miller GF, Spiegel S, Proia RL. 2007. Essential role for sphingosine kinases in neural and vascular development. Mol. Cell. Biol25:11113-21

164. Kimua A, Ohmori T, Ohkawa R, Madoiwa S, Mimuro J, et al.2007. Essential roles of sphingosine 1-phosphate/S1P1 receptor axis in the migration of neural stem cells toward a site of spinal cord injury. Stem Cells25:115-24 [PubMed: 16990586]

165. McGuire PG, Rangasamy S, Maestas J, Das A. 2011. Pericyte-derived sphingosine 1-phosphate induces the expression of adhesion proteins and modulates the retinal endothelial cell barrier. Arterioscler. Thromb. Vasc. Biol31:e107-15 [PubMed: 21940944]

166. Wei SH, Rosen H, Matheu MP, Sanna MG, Wang SK, et al.2005. Sphingosine 1-phosphate type 1 receptor agonism inhibits transendothelial migration of medullary $\mathrm{T}$ cells to lymphatic sinuses. Nat. Immunol6:1228-35 [PubMed: 16273098]

167. Liu Y, Wada R, Yamashita T, Mi Y, Deng CX, et al.2000. Edg-1, the G protein-coupled receptor for sphingosine-1-phosphate, is essential for vascular maturation. J. Clin. Investig106:951-61 [PubMed: 11032855]

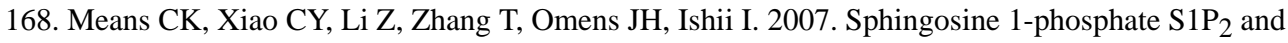
$\mathrm{S}_{1} \mathrm{P}_{3}$ receptor-mediated Akt activation protects against in vivo myocardial ischemia-reperfusion injury. Am. J. Physiol. Heart Circ. Physiol292:H2944-51 [PubMed: 17293497]

169. Kono M, Belyantseva IA, Skoura A, Frolenkov GI, Starost MF, et al.2007. Deafness and stria vascularis defects in $\mathrm{S}_{1} \mathrm{P}_{2}$ receptor-null mice. J. Biol. Chem282:10690-96 [PubMed: 17284444]

170. Herr DR, Grillet N, Schwander M, Rivera R, Muller U, Chun J. 2007. Sphingosine 1-phosphate (S1P) signaling is required for maintenance of hair cells mainly via activation of $\mathrm{S}_{\mathrm{P}} \mathrm{P}_{2} \mathrm{~J}$. Neurosci27:1474-78 [PubMed: 17287522]

171. Gu Y, Forostyan T, Sabbadini R, Rosenblatt J. 2011. Epithelial cell extrusion requires the sphingosine-1-phosphate receptor 2 pathway. J. Cell Biol193:667-76 [PubMed: 21555463]

172. Im DS, Tomura H, Tobo M, Sato K, Okajima F. 2004. Enhancement of sphingosine 1-phosphateinduced phospholipase $\mathrm{C}$ activation during $\mathrm{G}_{0}-\mathrm{G}_{1}$ transition in rat hepatocytes. J. Pharmacol. Sci95:283-90

173. Jolly PS, Rosenfeldt HM, Milstien S, Spiegel S. 2002. The roles of sphingosine-1-phosphate in asthma. Mol. Immunol38:1239-45 [PubMed: 12217390]

174. Takashima SI, Sugimoto N, Takuwa N, Okamoto Y, Yoshioka K, et al.2008. $\mathrm{G}_{12 / 13}$ and $\mathrm{G}_{\mathrm{q}}$ mediate $\mathrm{S}_{1} \mathrm{P}_{2}$-induced inhibition of Rac and migration in vascular smooth muscle in a manner dependent on Rho but not Rho kinase. Cardiovasc. Res79:689-97 [PubMed: 18480127]

175. Skoura A, Sanchez T, Claffey K, Mandala SM, Proia RL, Hla T. 2007. Essential role of sphingosine 1-phosphate receptor 2 in pathological angiogenesis of the mouse retina. J. Clin. Investig117:2506-16 [PubMed: 17710232]

176. Thurston G, Suri C, Smith K, McClain J, Sato TN, et al.1999. Leakage-resistant blood vessels in mice transgenically overexpressing angiopoietin-1. Science286:2511-14 [PubMed: 10617467]

177. Mammoto T, Parikh SM, Mammoto A, Gallagher D, Chan B, et al.2007. Angiopoietin-1 requires p190 RhoGAP to protect against vascular leakage in vivo. J. Biol. Chem282:23910-18 [PubMed: 17562701]

178. Baffert F, Le T, Thurston G, McDonald DM. 2006. Angiopoietin-1 decreases plasma leakage by reducing number and size of endothelial gaps in venules. Am. J. Physiol. Heart Circ. Physiol290:H107-18 [PubMed: 16126815]

179. Lee SW, Kim WJ, Jun HO, Choi YK, Kim KW. 2009. Angiopoietin-1 reduces vascular endothelial growth factor-induced brain endothelial permeability via upregulation of ZO-2. Int. J. Mol. Med23:279-84 [PubMed: 19148554]

180. Scharpfenecker M, Fiedler U, Reiss Y, Augustin HG. 2005. The Tie-2 ligand angiopoietin-2 destabilizes quiescent endothelium through an internal autocrine loop mechanism. J. Cell Sci118:771-80 [PubMed: 15687104]

181. Nag S, Papneja T, Venugopalan R, Stewart DJ. 2005. Increased angiopoietin2 expression is associated with endothelial apoptosis and blood-brain barrier breakdown. Lab. Investig. J. Tech. Methods Pathol85:1189-98 
182. Broman MT, Kouklis P, Gao X, Ramchandran R, Neamu RF, et al.2006. Cdc42 regulates adherens junction stability and endothelial permeability by inducing alpha-catenin interaction with the vascular endothelial cadherin complex. Circ. Res98:73-80 [PubMed: 16322481]

183. Stockton RA, Schaefer E, Schwartz MA. 2004. p21-activated kinase regulates endothelial permeability through modulation of contractility. J. Biol. Chem279:46621-30 [PubMed: 15333633]

184. Stockton R, Reutershan J, Scott D, Sanders J, Ley K, Schwartz MA. 2007. Induction of vascular permeability: $\beta$ PIX and GIT1 scaffold the activation of extracellular signal-regulated kinase by PAK. Mol. Biol. Cell18:2346-55 [PubMed: 17429073]

185. Orr AW, Stockton R, Simmers MB, Sanders JM, Sarembock IJ, et al.2007. Matrix-specific p21activated kinase activation regulates vascular permeability in atherogenesis. J. Cell Biol176:71927 [PubMed: 17312022]

186. Eriksson A, Cao R, Roy J, Tritsaris K, Wahlestedt C, et al.2003. Small GTP-binding protein Rac is an essential mediator of vascular endothelial growth factor-induced endothelial fenestrations and vascular permeability. Circulation107:1532-38 [PubMed: 12654612]

187. ten Dijke P, Arthur HM. 2007. Extracellular control of TGF $\beta$ signalling in vascular development and disease. Nat. Rev. Mol. Cell Biol8:857-69 [PubMed: 17895899]

188. Antonelli-Orlidge A, Saunders KB, Smith SR, D'Amore PA. 1989. An activated form of transforming growth factor beta is produced by cocultures of endothelial cells and pericytes. PNAS86:4544-48 [PubMed: 2734305]

189. Hirschi KK, Rohovsky SA, D'Amore PA. 1998. PDGF, TGF- $\beta$, and heterotypic cell-cell interactions mediate endothelial cell-induced recruitment of 10T1/2 cells and their differentiation to a smooth muscle fate. J. Cell Biol141:805-14 [PubMed: 9566978]

190. Neubauer K, Kruger M, Quondamatteo F, Knittel T, Saile B, Ramadori G. 1999. Transforming growth factor- $\beta 1$ stimulates the synthesis of basement membrane proteins laminin, collagen type IV and entactin in rat liver sinusoidal endothelial cells. J. Hepatol31:692-702 [PubMed: 10551394]

191. Walshe TE, Saint-Geniez M, Maharaj AS, Sekiyama E, Maldonado AE, D'Amore PA. 2009. TGF- $\beta$ is required for vascular barrier function, endothelial survival and homeostasis of the adult microvasculature. PLOS ONE4:e5149 [PubMed: 19340291]

192. Jerkic M, Letarte M. 2015. Increased endothelial cell permeability in endoglin-deficient cells. FASEB J. 29:3678-88 [PubMed: 25972355]

193. Lebrin F, Goumans MJ, Jonker L, Carvalho RL, Valdimarsdottir G, et al.2004. Endoglin promotes endothelial cell proliferation and TGF- $\beta$ /ALK1 signal transduction. EMBO J. 23:401828 [PubMed: 15385967]

194. van Meeteren LA, Goumans MJ, ten Dijke P. 2011. TGF-ßreceptor signaling pathways in angiogenesis; emerging targets for anti-angiogenesis therapy. Curr. Pharm. Biotechnol12:210820 [PubMed: 21619534]

195. Padua D, Zhang XH, Wang Q, Nadal C, Gerald WL, et al.2008. TGF $\beta$ primes breast tumors for lung metastasis seeding through angiopoietin-like 4. Cell133:66-77 [PubMed: 18394990]

196. Darland DC, Massingham LJ, Smith SR, Piek E, Saint-Geniez M, D’Amore PA. 2003. Pericyte production of cell-associated VEGF is differentiation-dependent and is associated with endothelial survival. Dev. Biol264:275-88 [PubMed: 14623248]

197. Pertovaara L, Kaipainen A, Mustonen T, Orpana A, Ferrara N, et al.1994. Vascular endothelial growth factor is induced in response to transforming growth factor- $\beta$ in fibroblastic and epithelial cells. J. Biol. Chem269:6271-74 [PubMed: 8119973]

198. Enholm B, Paavonen K, Ristimaki A, Kumar V, Gunji Y, et al.1997. Comparison of VEGF, VEGF-B, VEGF-C and Ang-1 mRNA regulation by serum, growth factors, oncoproteins and hypoxia. Oncogene14:2475-83 [PubMed: 9188862]

199. Simionescu N, Simionescu M, Palade GE. 1978. Open junctions in the endothelium of the postcapillary venules of the diaphragm. J. Cell Biol79:27-44 [PubMed: 701375]

200. Palade GE, Simionescu M, Simionescu N. 1979. Structural aspects of the permeability of the microvascular endothelium. Acta Physiol. Scand. Supp1463:11-32 [PubMed: 382743] 
201. Feng Y, Venema VJ, Venema RC, Tsai N, Behzadian MA, Caldwell RB. 1999. VEGFinduced permeability increase is mediated by caveolae. Investig. Ophthalmol. Vis. Sci40:157-67 [PubMed: 9888439]

202. Garcia CM, Darland DC, Massingham LJ, D’Amore PA. 2004. Endothelial cell-astrocyte interactions and TGF $\beta$ are required for induction of blood-neural barrier properties. Dev. Brain Res152:25-38 [PubMed: 15283992]

203. Tiruppathi C, Malik AB, Del Vecchio PJ, Keese CR, Giaever I. 1992. Electrical method for detection of endothelial cell shape change in real time: assessment of endothelial barrier function. PNAS89:7919-23 [PubMed: 1518814]

204. Miles AA, Miles EM. 1952. Vascular reactions to histamine, histamine-liberator and leukotaxine in the skin of guinea-pigs. J. Physiol118:228-57 [PubMed: 13000707]

205. Nagy JA, Feng D, Vasile E, Wong WH, Shih SC, Dvorak AM, Dvorak HF. 2006. Permeability properties of tumor surrogate blood vessels induced by VEGF-A. Lab. Investig. J. Tech. Methods Pathol86:767-80

206. Nagy JA, Shih SC, Wong WH, Dvorak AM, Dvorak HF. 2008. Chapter 3. The adenoviral vector angiogenesis/lymphangiogenesis assay. Methods Enzymol. 444:43-64 [PubMed: 19007660]

207. Thurston G, Baluk P, Hirata A, McDonald DM. 1996. Permeability-related changes revealed at endothelial cell borders in inflamed venules by lectin binding. Am. J. Physiol271:H2547-62 [PubMed: 8997316]

208. Egawa G, Nakamizo S, Natsuaki Y, Doi H, Miyachi Y, Kabashima K. 2013. Intravital analysis of vascular permeability in mice using two-photon microscopy. Sci. Rep3:1932 [PubMed: 23732999]

209. Carmeliet P2003. Angiogenesis in health and disease. Nat. Med9:653-60 [PubMed: 12778163]

210. Clarke JM, Hurwitz HI. 2013. Understanding and targeting resistance to anti-angiogenic therapies. J. Gastrointest. Oncol4:253-63 [PubMed: 23997938]

211. Eelen G, de Zeeuw P, Simons M, Carmeliet P. 2015. Endothelial cell metabolism in normal and diseased vasculature. Circ. Res116:1231-44 [PubMed: 25814684]

212. Welti J, Loges S, Dimmeler S, Carmeliet P. 2013. Recent molecular discoveries in angiogenesis and antiangiogenic therapies in cancer. J. Clin. Investig 123:3190-200 [PubMed: 23908119]

213. Jain RK. 2014. Antiangiogenesis strategies revisited: from starving tumors to alleviating hypoxia. Cancer Cell26:605-22 [PubMed: 25517747]

214. Dvorak HF, Harvey VS, Estrella P, Brown LF, McDonagh J, Dvorak AM. 1987. Fibrin containing gels induce angiogenesis. Implications for tumor stroma generation and wound healing. Lab. Investig. J. Tech. Methods Pathol57:673-86

215. Ananthnarayan S, Bahng J, Roring J, Nghiemphu P, Lai A, Cloughesy T, Pope WB. 2008. Time course of imaging changes of GBM during extended bevacizumab treatment. J. NeuroOncol88:339-47

216. Numnum TM, Rocconi RP, Whitworth J, Barnes MN. 2006. The use of bevacizumab to palliate symptomatic ascites in patients with refractory ovarian carcinoma. Gynecol. Oncol102:425-28 [PubMed: 16797681]

217. Hurwitz H, Fehrenbacher L, Novotny W, Cartwright T, Hainsworth J, et al.2004. Bevacizumab plus irinotecan, fluorouracil, and leucovorin for metastatic colorectal cancer. N. Engl. J. Med350:2335-42 [PubMed: 15175435]

218. Sandler A, Gray R, Perry MC, Brahmer J, Schiller JH, et al.2006. Paclitaxel-carboplatin alone or with bevacizumab for non-small-cell lung cancer. N. Engl. J. Med355:2542-50 [PubMed: 17167137]

219. Escudier B, Eisen T, Stadler WM, Szczylik C, Oudard S, et al.2007. Sorafenib in advanced clear-cell renal-cell carcinoma. N. Engl. J. Med356:125-34 [PubMed: 17215530]

220. Motzer RJ, Hutson TE, Tomczak P, Michaelson MD, Bukowski RM, et al.2007. Sunitinib versus interferon alfa in metastatic renal-cell carcinoma. N. Engl. J. Med356:115-24 [PubMed: 17215529]

221. Kadenhe-Chiweshe A, Papa J, McCrudden KW, Frischer J, Bae JO, et al.2008. Sustained VEGF blockade results in microenvironmental sequestration of VEGF by tumors and persistent VEGF receptor-2 activation. Mol. Cancer Res.: MCR6:1-9 [PubMed: 18234958] 
222. Byrne AT, Ross L, Holash J, Nakanishi M, Hu L, et al.2003. Vascular endothelial growth factor-trap decreases tumor burden, inhibits ascites, and causes dramatic vascular remodeling in an ovarian cancer model. Clin. Cancer Res.: Off. J. Am. Assoc. Cancer Res9:5721-28

223. Garcia A, Singh H. 2013. Bevacizumab and ovarian cancer. Ther. Adv. Med. Oncol5:133-41 [PubMed: 23450196]

224. Leow CC, Coffman K, Inigo I, Breen S, Czapiga M, et al.2012. MEDI3617, a human antiangiopoietin 2 monoclonal antibody, inhibits angiogenesis and tumor growth in human tumor xenograft models. Int. J. Oncol40:1321-30 [PubMed: 22327175]

225. Goel S, Gupta N, Walcott BP, Snuderl M, Kesler CT, et al.2013. Effects of vascular-endothelial protein tyrosine phosphatase inhibition on breast cancer vasculature and metastatic progression. J. Natl. Cancer Inst105:1188-201 [PubMed: 23899555]

226. Wang H, Song S, Kou G, Li B, Zhang D, et al.2007. Treatment of hepatocellular carcinoma in a mouse xenograft model with an immunotoxin which is engineered to eliminate vascular leak syndrome. Cancer Immunol. Immunother.: CII56:1775-83 [PubMed: 17431617]

227. Lee JM, Zhai G, Liu Q, Gonzales ER, Yin K, et al.2007. Vascular permeability precedes spontaneous intracerebral hemorrhage in stroke-prone spontaneously hypertensive rats. Stroke J. Cereb. Circ38:3289-91

228. Esser S, Lampugnani MG, Corada M, Dejana E, Risau W. 1998. Vascular endothelial growth factor induces VE-cadherin tyrosine phosphorylation in endothelial cells. J. Cell Sci111(Pt. 13):1853-65 [PubMed: 9625748]

229. Miyahara T, Hamanaka K, Weber DS, Drake DA, Anghelescu M, Parker JC. 2007. Phosphoinositide 3-kinase, Src, and Akt modulate acute ventilation-induced vascular permeability increases in mouse lungs. Am. J. Physiol. Lung Cell. Mol. Physiol293:L11-21 [PubMed: 17322282]

230. Simorre-Pinatel V, Guerrin M, Chollet P, Penary M, Clamens S, et al.1994. Vasculotropin-VEGF stimulates retinal capillary endothelial cells through an autocrine pathway. Investig. Ophthalmol. Vis. Sci35:3393-400 [PubMed: 8056513]

231. Aiello LP, Pierce EA, Foley ED, Takagi H, Chen H, et al.1995. Suppression of retinal neovascularization in vivo by inhibition of vascular endothelial growth factor (VEGF) using soluble VEGF-receptor chimeric proteins. PNAS92:10457-61 [PubMed: 7479819]

232. Pierce EA, Avery RL, Foley ED, Aiello LP, Smith LE. 1995. Vascular endothelial growth factor/vascular permeability factor expression in a mouse model of retinal neovascularization. PNAS92:905-9 [PubMed: 7846076]

233. Kergoat H, Herard ME, Lemay M. 2006. RGC sensitivity to mild systemic hypoxia. Investig. Ophthalmol. Vis. Sci47:5423-27 [PubMed: 17122132]

234. Seko Y, Fujikura H, Pang J, Tokoro T, Shimokawa H. 1999. Induction of vascular endothelial growth factor after application of mechanical stress to retinal pigment epithelium of the rat in vitro. Investig. Ophthalmol. Vis. Sci40:3287-91 [PubMed: 10586955]

235. Mousa SA, Lorelli W, Campochiaro PA. 1999. Role of hypoxia and extracellular matrix-integrin binding in the modulation of angiogenic growth factors secretion by retinal pigmented epithelial cells. J. Cell. Biochem74:135-43 [PubMed: 10381270]

236. Miller JW, Adamis AP, Shima DT, D'Amore PA, Moulton RS, et al.1994. Vascular endothelial growth factor/vascular permeability factor is temporally and spatially correlated with ocular angiogenesis in a primate model. Am. J. Pathol145:574-84 [PubMed: 7521577]

237. Shima DT, Adamis AP, Ferrara N, Yeo KT, Yeo TK, et al.1995. Hypoxic induction of endothelial cell growth factors in retinal cells: identification and characterization of vascular endothelial growth factor (VEGF) as the mitogen. Mol. Med1:182-93 [PubMed: 8529097]

238. Mintz-Hittner HA, Kennedy KA, Chuang AZ. 2011. Efficacy of intravitreal bevacizumab for stage 3+ retinopathy of prematurity. N. Engl. J. Med364:603-15 [PubMed: 21323540]

239. Tornquist P, Alm A, Bill A. 1990. Permeability of ocular vessels and transport across the blood-retinal-barrier. Eye4(Pt. 2):303-9 [PubMed: 2199237]

240. Rosenfeld PJ, Brown DM, Heier JS, Boyer DS, Kaiser PK, et al.2006. Ranibizumab for neovascular age-related macular degeneration. N. Engl. J. Med355:1419-31 [PubMed: 17021318] 
241. Saint-Geniez M, Maharaj AS, Walshe TE, Tucker BA, Sekiyama E, et al.2008. Endogenous VEGF is required for visual function: evidence for a survival role on muller cells and photoreceptors. PLOS ONE3:e3554 [PubMed: 18978936]

242. Saint-Geniez M, Kurihara T, Sekiyama E, Maldonado AE, D'Amore PA. 2009. An essential role for RPE-derived soluble VEGF in the maintenance of the choriocapillaris. PNAS106:18751-56 [PubMed: 19841260]

243. Kamba T, Tam BY, Hashizume H, Haskell A, Sennino B, et al.2006. VEGF-dependent plasticity of fenestrated capillaries in the normal adult microvasculature. Am. J. Physiol. Heart Circ. Physiol290:H560-76 [PubMed: 16172168]

244. Peters S, Heiduschka P, Julien S, Ziemssen F, Fietz H, et al.2007. Ultrastructural findings in the primate eye after intravitreal injection of bevacizumab. Am. J. Ophthalmol143:995-1002 [PubMed: 17449002]

245. Ford KM, Saint-Geniez M, Walshe T, Zahr A, D'Amore PA. 2011. Expression and role of VEGF in the adult retinal pigment epithelium. Investig. Ophthalmol. Vis. Sci52:9478-87 [PubMed: 22058334]

246. Inai T, Mancuso M, Hashizume H, Baffert F, Haskell A, et al.2004. Inhibition of vascular endothelial growth factor (VEGF) signaling in cancer causes loss of endothelial fenestrations, regression of tumor vessels, and appearance of basement membrane ghosts. Am. J. Pathol165:35-52 [PubMed: 15215160]

247. Vinores SA. 2006. Pegaptanib in the treatment of wet, age-related macular degeneration. Int. J. Nanomed 1:263-68

248. Lowe J, Araujo J, Yang J, Reich M, Oldendorp A, et al.2007. Ranibizumab inhibits multiple forms of biologically active vascular endothelial growth factor in vitro and in vivo. Exp. Eye Res85:425-30 [PubMed: 17714704] 


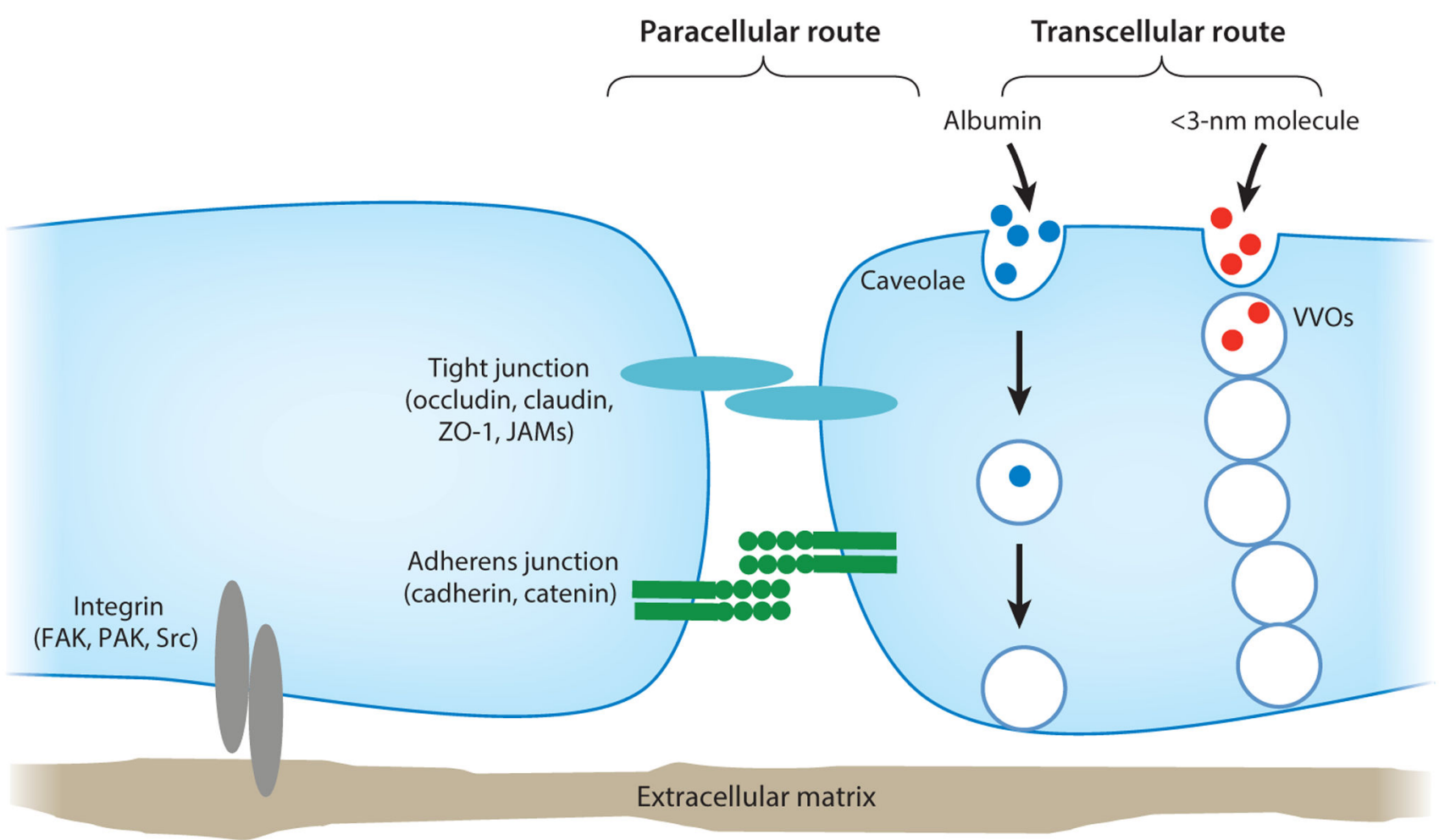

Figure 1.

Transcellular and paracellular pathways in endothelial cells. The passage of macromolecules, fluids, and cells through the endothelial barrier can occur through transcellular (vesiculo-vacuolar organelles) or paracellular (tight and adherens junctions) pathways. Abbreviations: JAM, junctional adhesion molecule; VVO, vesiculo-vacuolar organelle; ZO, zona occludens. 

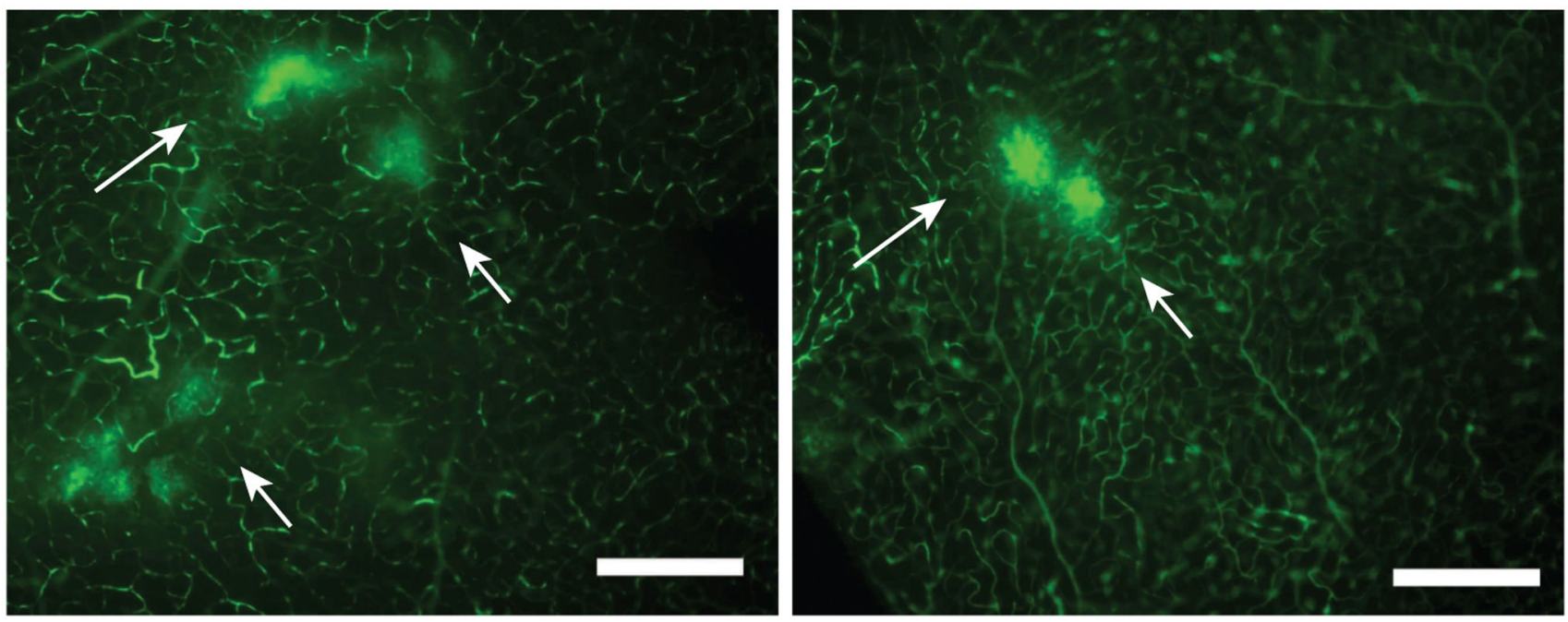

Figure 2.

Pericyte loss in the retinal microvasculature is associated with microvascular permeability. iDTR;M-Cre mice were generated by breeding Cre-inducible DT receptor-transgenic mice

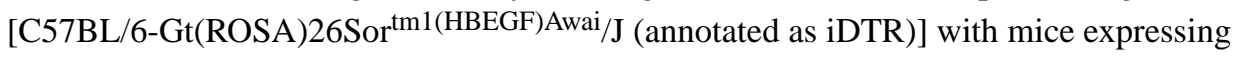
tamoxifen-inducible Cre under the control of the SMMHC promoter (annotated as M-Cre). DT-treated iDTR;M-Cre mice were perfused with fluorescein dextran $\left(2 \times 10^{6} \mathrm{~mW}\right)$ before retinal imaging by fluorescence microscopy. Arrows indicate sites of increased microvascular permeability in the retinal microvasculature of mice with inducible mural cell loss. Scale bar: $250 \mu \mathrm{m}$. Abbreviations: DT, diphtheria toxin; SMMHC, smooth muscle myosin heavy chain. Unpublished photo by C. Valdez, J. Arboleda, and P.A. D'Amore. 

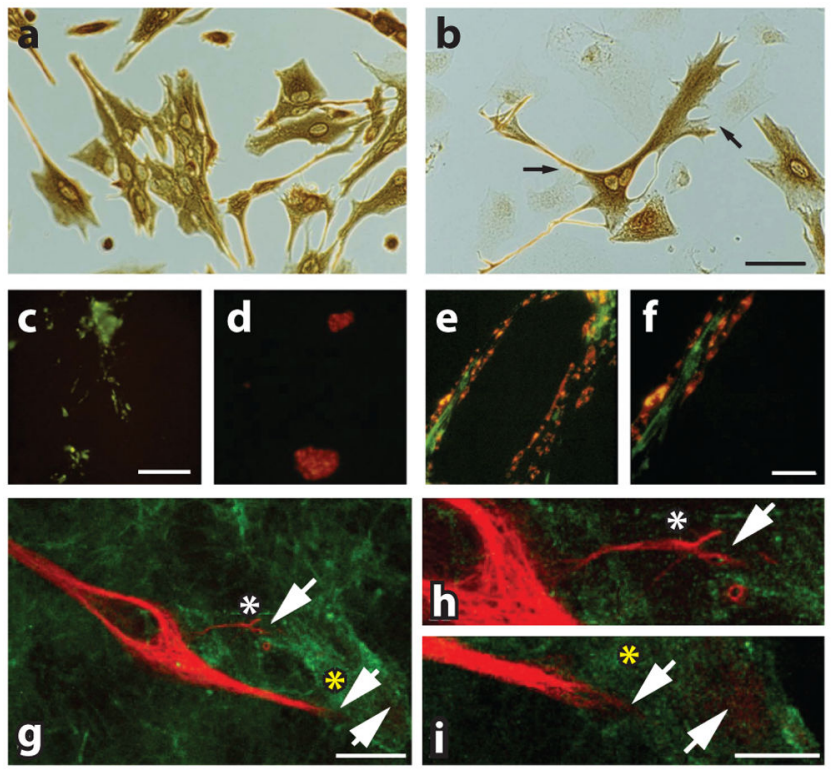

Figure 3.

Astrocyte-endothelial cell cocultures and time course of TER. (a-1) Brain astrocytes were isolated from rat pups at postnatal day 1 , plated onto tissue culture flasks, and allowed to grow for 7-10 days. Cells were cultured on tissue culture plastic, in Matrigel or on Transwell membranes for morphological comparison. $(a, b)$ Astrocytes immunolabeled with GFAP were cultured (a) for $24 \mathrm{~h}$ alone or $(b)$ in coculture with rat microvascular ECs on tissue culture plastic. Arrows indicate ECs next to astrocytes. Astrocytes and bovine microvascular ECs were grown alone and in coculture in a three-dimensional Matrigel assay for $24 \mathrm{~h}$. (c) Astrocytes were labeled green and (d) ECs were labeled red to distinguish the cell populations. $(e, f)$ Astrocytes and ECs were grown in Matrigel coculture. $(g-1)$ Astrocytes and bovine microvascular ECs were grown on opposite sides of a Transwell membrane and identified with GFAP labeling (red) or simplicifolia lectin (green), respectively, to distinguish the cell types. The arrows indicate areas of astrocyte contact with ECs, and asterisks indicate areas shown in higher magnification. (j) ECs were plated onto 12 well Transwell inserts alone (green triangles), cocultured with astrocytes on the underside of the well (orange circles), or cocultured with BAE on the underside of the well (blue squares). TER was measured daily with a Millipore electrical resistance unit. TER from an empty Transwell was used as background and was subtracted from EC readings. The average of triplicate measures from each well was used to calculate TER/cm ${ }^{2}$. Readings were measured from triplicate wells. Scale bar: $20 \mu \mathrm{m}$ in panels $a-e$ and $g-i$ and $40 \mu \mathrm{m}$ in panel $f$. Abbreviations: BAE, bovine aortic endothelium; EC, endothelial cell; GFAP, glial fibrillary acidic protein; TER, transendothelial electrical resistance. Figure adapted from Reference 202 with permission from Elsevier Limited. 
VEGF-A $50 \mathrm{ng}$

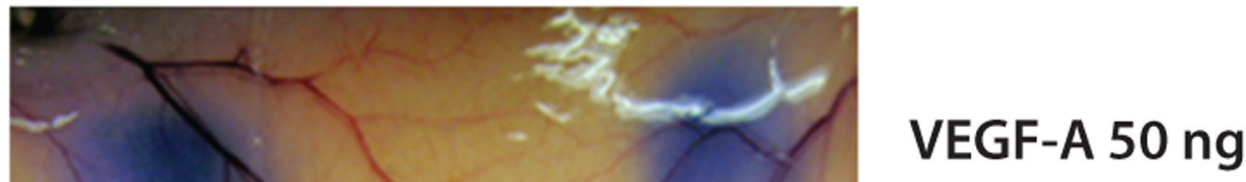

\section{VEGF-A $100 \mathrm{ng}$}

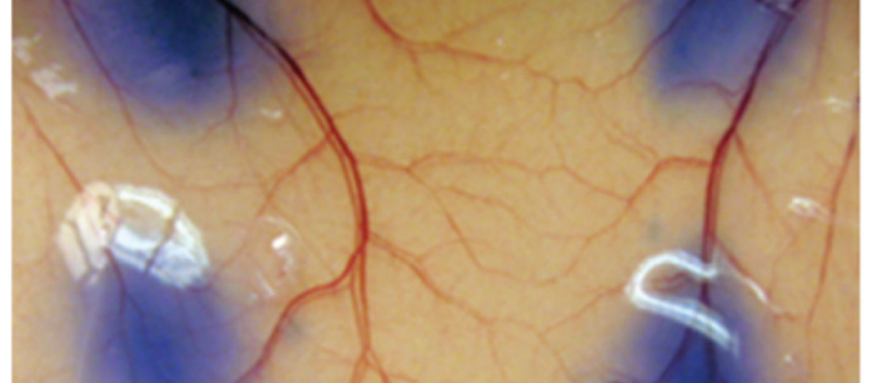

VEGF-A $100 \mathrm{ng}$

HBSS

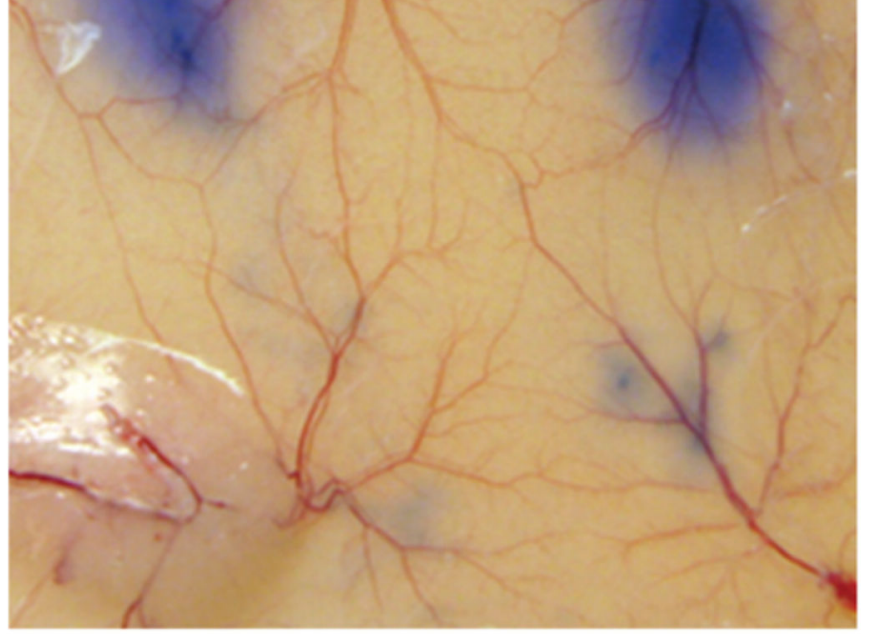

HBSS

Figure 4.

Miles permeability assay. Different concentrations of VEGF-A were injected subcutaneously into mice, followed immediately by an intravenous injection of Evans blue dye. HBSS was injected as a control. Abbreviations: HBSS, Hanks' buffered saline solution; VEGF-A, vascular endothelial growth factor-A. Image courtesy of Janice Nagy and Harold Dvorak (Department of Pathology, Beth Israel Deaconess Medical Center, Harvard Medical School, Boston, Massachusetts 02115). 


\section{Table 1}

VEGF-induced cell signaling and related biological effects in endothelial cells

\begin{tabular}{|c|c|c|c|}
\hline Cell type(s) & Biological effect(s) & Signaling response(s) & Reference(s) \\
\hline Human umbilical vein ECs & $\begin{array}{l}\text { Cell survival; inhibition } \\
\text { of apoptosis }\end{array}$ & KDR-mediated PI3K and Akt activation & 59 \\
\hline Human umbilical vein ECs & $\begin{array}{l}\text { Cell survival; gene } \\
\text { expression }\end{array}$ & Upregulation of Bcl-2 & 59 \\
\hline Human umbilical vein ECs & Cell survival & Upregulation of XIAP and survivin & 68 \\
\hline $\begin{array}{l}\text { Human umbilical vein ECs } \\
\text { Human dermal microvascular } \\
\text { ECs }\end{array}$ & Cell migration & $\begin{array}{l}\text { Akt-dependent eNOS phosphorylation } \\
\text { PLD activation } \\
\text { Rac1 activity } \\
\text { Activation of Rac1 and Rac GEF; Vav2 association with } \\
\text { G15ARac1 }\end{array}$ & $69-72$ \\
\hline Human umbilical vein ECs & $\begin{array}{l}\text { Cell migration; focal } \\
\text { adhesion formation }\end{array}$ & $\begin{array}{l}\text { ERK1/2 activation; tyrosine phosphorylation of PLC- } \gamma \text { and } \\
\text { FAK } \\
\text { a } 3 \text { integrin tyrosine phosphorylation via c-Src } \\
\text { Integrin signaling via c-Src and FAK in CD63-ablated cells }\end{array}$ & $73-75$ \\
\hline Human umbilical vein ECs & $\begin{array}{l}\text { Cell directional } \\
\text { migration; vascular } \\
\text { sprouting }\end{array}$ & $\begin{array}{l}\text { Phosphorylation of PLC } \beta 3 \text { is dependent on the VEGF- } \\
\text { VEGFR2 axis }\end{array}$ & 76 \\
\hline Human umbilical vein ECs & $\begin{array}{l}\text { Cell-cell contact; cell } \\
\text { migration }\end{array}$ & Actin-binding protein IQGAP1 & 77 \\
\hline Human umbilical vein ECs & $\begin{array}{l}\text { Cell migration and } \\
\text { permeability }\end{array}$ & $\begin{array}{l}\text { Phosphorylation of VE-cadherin, } \beta \text {-catenin, plakoglobin, p120, } \\
\text { and PECAM-1 }\end{array}$ & 228 \\
\hline Human umbilical vein ECs & $\begin{array}{l}\text { Cell migration; actin } \\
\text { filament reorganization }\end{array}$ & $\begin{array}{l}\text { Recruitment of vinculin to focal adhesions; ERK and p38 } \\
\text { stimulation; Hsp 90-dependent FAK phosphorylation } \\
\text { TSAd forms complex with Src } \\
\text { Activation of SAPK2/p38 MAPK Generation of PIP3 activates } \\
\text { Rac }\end{array}$ & $78-82$ \\
\hline $\begin{array}{l}\text { Human umbilical vein ECs } \\
\text { Porcine aortic ECs }\end{array}$ & $\begin{array}{l}\text { Cell migration and } \\
\text { proliferation }\end{array}$ & $\begin{array}{l}\text { NO-mediated depression of PKC } 8 \text { activity } \\
\text { VEGFR2-pY1175/1173 is required for PI } 3 \text { kinase activation } \\
\text { Gq/11 and } \mathrm{G} \beta \gamma \text { proteins are required for VEGF-stimulated } \\
\text { intracellular } \mathrm{Ca}^{2+} \text { mobilization }\end{array}$ & $83-85$ \\
\hline $\begin{array}{l}\text { Human umbilical vein ECs } \\
\text { Bovine aortic ECs }\end{array}$ & Cell proliferation & $\begin{array}{l}\text { PKCa and PKCS translocation and specific inhibition using } \\
\text { antisense } \\
\beta 3 \text { integrin and KDR-mediated PI3 kinase stimulation } \\
\text { Raf- } 1 \text { and PKG activation } \\
\text { Ca2 } 1 \text { and PI } 3 K-\text { mediated cGMP increase and eNOS } \\
\text { upregulation } \\
\text { PTP1B negatively regulates VEGFR } 2 \text { autophosphorylation, } \\
\text { inhibiting Erk1/2 phosphorylation } \\
\text { Activation of PKD modulates Erk1/2 pathway }\end{array}$ & $86-91$ \\
\hline Bovine pulmonary artery ECs & $\begin{array}{l}\text { Cell proliferation and } \\
\text { permeability }\end{array}$ & $\begin{array}{l}\text { Loss of } \beta \text {-catenin staining from adherens junctions; PLC- } \gamma \text {, } \\
\text { paxillin, and } \beta \text {-catenin phosphorylation }\end{array}$ & 92 \\
\hline $\begin{array}{l}\text { Bovine retinal ECs } \\
\text { Bovine microvascular ECs } \\
\text { Porcine brain microvascular } \\
\text { ECs } \\
\text { Porcine isolated coronary } \\
\text { venules }\end{array}$ & Cell permeability & $\begin{array}{l}\text { Activation of ERK and cPLA2 } \\
\text { NO and PGI } 2 \text { production } \\
\text { cGMP production } \\
\text { PLC- } \gamma \text { phosphorylation; PKC-mediated eNOS phosphorylation }\end{array}$ & $93-96$ \\
\hline $\begin{array}{l}\text { Human dermal microvascular } \\
\text { ECs }\end{array}$ & Angiogenesis & Increased expression of a $1 \beta 1$ and a $2 \beta 1$ integrins & 97 \\
\hline $\begin{array}{l}\text { Human umbilical vein ECs } \\
\text { Bovine aortic ECs }\end{array}$ & DNA synthesis & $\begin{array}{l}\text { Phosphorylation of PLC- } \gamma, \text { FAK, AKT, and } \\
\text { Erk; PKC } \text { translocation } \\
\text { ERK activation } \\
\text { ERK-mediated JNK activation; cyclin D1 synthesis; Cdk4 } \\
\text { activation } \\
\text { PKCaand PKC } \beta \text { translocation; PLC- } \gamma \text { phosphorylation; PI3K }\end{array}$ & $98-101$ \\
\hline
\end{tabular}




\begin{tabular}{|c|c|c|c|}
\hline Cell type(s) & Biological effect(s) & Signaling response(s) & Reference(s) \\
\hline & & $\begin{array}{l}\text { activation } \\
\text { NOS ser1177 phosphorylation }\end{array}$ & \\
\hline $\begin{array}{l}\text { Sinusoidal ECs } \\
\text { Porcine aortic ECs }\end{array}$ & $\begin{array}{l}\text { DNA synthesis; PKC- } \\
\text { dependent ERK } \\
\text { activation }\end{array}$ & $\begin{array}{l}\text { Activation of Raf-1; Mek, ERK, and PKC } \beta \text { translocation } \\
\text { Shc-Grb2 complex formation }\end{array}$ & $102-104$ \\
\hline Human umbilical vein ECs & $\begin{array}{l}\text { NO production; gene } \\
\text { expression }\end{array}$ & Upregulation of eNOS & 88,105 \\
\hline Postcapillary endothelial cells & $\begin{array}{l}\text { NO-mediated ERK } \\
\text { activation }\end{array}$ & NO production; ERK activation & 106 \\
\hline Human umbilical vein ECs & $\begin{array}{l}\mathrm{Ca}^{2+} \text {-independent } \mathrm{NO} \\
\text { production }\end{array}$ & Occludin and ZO-1 tyrosine phosphorylation & 107,108 \\
\hline Bovine aortic ECs & $\begin{array}{l}\text { NO production; PGI } \\
\text { production }\end{array}$ & $\begin{array}{l}\text { Association of Src with KDR; PLC- } \gamma \text { activation; intracellular } \\
\mathrm{Ca}^{2+} \text { mobilization }\end{array}$ & 109 \\
\hline Human umbilical vein ECs & Tissue factor production & Flt1 activation & 110 \\
\hline $\begin{array}{l}\text { Bovine retinal ECs } \\
\text { Bovine adrenal cortex ECs }\end{array}$ & Gene expression & $\begin{array}{l}\text { ERK and PKC-mediated upregulation of Ang-2 } \\
\text { PKC-mediated eNOS upregulation }\end{array}$ & 111,112 \\
\hline Porcine aortic ECs & $\begin{array}{l}\text { VEGFR2-specific } \\
\text { signaling and } \\
\text { proliferation }\end{array}$ & $\begin{array}{l}\text { Grb2 and Nck association with KDR; SHP1 and SHP2 } \\
\text { association with KDR }\end{array}$ & 104 \\
\hline $\begin{array}{l}\text { Human umbilical vein ECs } \\
\text { Porcine aortic ECs }\end{array}$ & $\begin{array}{l}\text { VEGFR2-specific } \\
\text { signaling }\end{array}$ & $\begin{array}{l}\mathrm{Ca}^{2+} \text { mobilization } \\
\mathrm{NO} \text { and cGMP production }\end{array}$ & 113,114 \\
\hline Bovine retinal ECs & Intracellular trafficking & KDR, caveolin-1, and eNOS translocation to the nucleus & 201 \\
\hline
\end{tabular}

Abbreviations: EC, endothelial cell; eNOS, endothelial nitric oxide synthase; ERK, extracellular signal-regulated kinase; FAK, focal adhesion tyrosine kinase; PECAM-1, platelet-endothelial cell adhesion molecule; VEGF, vascular endothelial growth factor. 
Table 2

\section{Breakdown of VE-cadherin junctions and the endothelial barrier}

\begin{tabular}{|c|c|c|}
\hline $\begin{array}{l}\text { Route(s) of VE- } \\
\text { cadherin disassembly } \\
\text { and vascular } \\
\text { permeability }\end{array}$ & Cellular function(s) & Reference(s) \\
\hline $\begin{array}{l}\text { VE-cadherin } \\
\text { phosphorylation }\end{array}$ & $\begin{array}{l}\text { Putative phospho-tyrosine sites of VE-cadherin are implicated in barrier integrity } \\
\text { VE-cadherin serine phosphorylation modulates adherens junction assembly } \\
\text { VE-cadherin/catenin complexes hamper vascular permeability and leukocyte extravasation } \\
\text { Nonreceptor tyrosine kinase Src leads to phosphorylation of VE-cadherin and catenins, and } \\
\text { to adherens junction disassembly } \\
\text { Src-directed VE-cadherin phosphorylation is insufficient to drive endothelial barrier opening } \\
\text { FAK mediates adherens junction disorganization and permeability }\end{array}$ & $30,119,122-131$ \\
\hline $\begin{array}{l}\text { VE-cadherin } \\
\text { phosphorylation }\end{array}$ & $\begin{array}{l}\text { Activation of small GTPases, including RhoA, Rac, and cdc42, and myosin light chain } \\
\text { phosphorylation depend on cellular context and extracellular cues } \\
\text { Rac mediates VEGF-induced permeability upon VE-cadherin transactivation }\end{array}$ & 132,133 \\
\hline $\begin{array}{l}\text { VE-cadherin and } \\
\text { mechanical forces }\end{array}$ & $\begin{array}{l}\text { Regulation of cell-cell adhesion and endothelial barrier function } \\
\text { Endosomal trafficking through clathrin-coated vesicles } \\
\text { Migration and permeability } \\
\text { p120-catenin modulates VE-cadherin endocytosis } \\
\text { PI3K signaling is involved in VE-cadherin internalization and loss of vascular barrier } \\
\text { Antipermeability agents operate through the blockade of VE-cadherin internalization }\end{array}$ & $\begin{array}{l}119,120,123 \\
128,134-142\end{array}$ \\
\hline VE-cadherin availability & $\begin{array}{l}\text { KLF4 depletion leads to VE-cadherin reduction and loss of adheren junctions and barrier } \\
\text { integrity } \\
\text { Wnt } 3 \text { a/ } \beta \text {-catenin signaling controls claudin-3 expression and barrier maturation } \\
\text { Loss of catenin p120 leads to VE-cadherin downregulation, microvasculature } \\
\text { disorganization, and loss of vascular integrity in mice } \\
\text { miR27a, miR101, miR125b, and miR142a modulate VE-cadherin expression, } \\
\text { angiogenesis, and vascular permeability }\end{array}$ & $143-149$ \\
\hline
\end{tabular}

Abbreviations: FAK, focal adhesion tyrosine kinase; VE-cadherin, vascular endothelial cadherin. 
Table 3

Sphingosine-1-phosphate receptor subtypes involved in vascular permeability

\begin{tabular}{|c|c|c|c|}
\hline $\begin{array}{l}\text { S1P } \\
\text { subtype }\end{array}$ & Tissue expression & Function(s) & Reference(s) \\
\hline $\mathrm{S}_{1} \mathrm{P}_{1}$ & $\begin{array}{l}\text { Brain and heart } \\
\text { Spleen and liver } \\
\text { Lung, thymus, kidney, and } \\
\text { skeletal muscle } \\
\text { Lymphoid }\end{array}$ & $\begin{array}{l}\text { Astrocyte migration } \\
\text { Blockade of egress and chemotaxis in B cells } \\
\text { Increase in } \beta \text {-AR-positive inotrophy induces calcium overload in cardiomyocytes } \\
\text { Endothelial cell: early vascular development; adherens junction assembly; APC- } \\
\text { mediated increased barrier integrity; Rho-dependent activation of integrins; } \\
\text { activation of matrix-degrading proteinases; barrier protection } \\
\text { Neural stem cell migration } \\
\text { Pericyte: early vascular development adhesion protein and barrier integrity } \\
\text { Blockade of egress and chemotaxis decreased late-stage maturation in T cells } \\
\text { Inhibition of Rac activation; recruitment of VSMCs }\end{array}$ & $134,154-167$ \\
\hline $\mathrm{S}_{1} \mathrm{P}_{2}$ & $\begin{array}{l}\text { Brain and heart } \\
\text { Spleen and liver } \\
\text { Lung, thymus, kidney, and } \\
\text { skeletal muscle }\end{array}$ & $\begin{array}{l}\text { Cardiomyocyte survival } \\
\text { Apoptotic cell extrusion of epithelial cells } \\
\text { Endothelial cell: pathological angiogenesis adherens junction disruption } \\
\text { Proliferation and matrix remodeling in hepatocyte } \\
\text { Mast cell degranulation } \\
\text { Reduced PDGF-induced migration of VSMCs }\end{array}$ & $168-175$ \\
\hline
\end{tabular}

Abbreviations: S1P, sphingosine-1-phosphate; VSMC, vascular smooth muscle cell. 
Table 4

Methods to evaluate vascular permeability

\begin{tabular}{|c|c|c|c|c|}
\hline & Model & Description & Advantage(s) & Disadvantage(s) \\
\hline \multirow[t]{4}{*}{ In vitro } & Transwell assay & $\begin{array}{l}\text { Measures the accumulation of } \\
\text { tracer in lower chamber }\end{array}$ & $\begin{array}{l}\text { Visualizes cells using microscopy and } \\
\text { immunohistochemistry }\end{array}$ & $\begin{array}{l}\text { Relies on absolute confluence } \\
\text { of monolayer }\end{array}$ \\
\hline & $\begin{array}{l}\text { Transendothelial } \\
\text { resistance }\end{array}$ & $\begin{array}{l}\text { Measures changes in } \\
\text { resistance or impedance } \\
\text { across confluent monolayer }\end{array}$ & $\begin{array}{l}\text { Measures rapid and reversible } \\
\text { responses }\end{array}$ & $\begin{array}{l}\text { Represents cell-cell and cell- } \\
\text { matrix interactions }\end{array}$ \\
\hline & $\begin{array}{l}\text { Electrical cell- } \\
\text { substrate impedance } \\
\text { sensor }\end{array}$ & $\begin{array}{l}\text { Analyzes the impedance } \\
\text { spectrum of adherent cells } \\
\text { using electrodes }\end{array}$ & $\begin{array}{l}\text { Measures impedance and can } \\
\text { differentiate between junctional } \\
\text { impedance and impedance caused by } \\
\text { cell-substrate interactions }\end{array}$ & $\begin{array}{l}\text { Does not provide direct } \\
\text { information on the molecular } \\
\text { level }\end{array}$ \\
\hline & Microcarrier beads & $\begin{array}{l}\text { Assesses tracers that pass } \\
\text { through cell monolayers into } \\
\text { a bead matrix }\end{array}$ & Measures very rapid changes & $\begin{array}{l}\text { May have heterogeneous } \\
\text { endothelial cell confluency } \\
\text { among microcarrier beads }\end{array}$ \\
\hline \multirow[t]{4}{*}{ In vivo } & Miles assay & $\begin{array}{l}\text { Extravasates tracer from } \\
\text { blood vessels in the skin } \\
\text { via local injection of a } \\
\text { permeability-inducing agent }\end{array}$ & $\begin{array}{l}\text { Quantifies labeled tracers by } \\
\text { extraction }\end{array}$ & $\begin{array}{l}\text { May vary depending on vessel } \\
\text { morphology in skin }\end{array}$ \\
\hline & $\begin{array}{l}\text { First-order model } \\
\text { of albumin kinetics } \\
\text { using a dual isotope } \\
\text { approach }\end{array}$ & $\begin{array}{l}\text { Measures tracers to estimate } \\
\text { the permeability-surface area } \\
\text { for albumin }\end{array}$ & $\begin{array}{l}\text { Measures rate of albumin leakage into } \\
\text { tissue } \\
\text { Simple to implement in a small animal } \\
\text { model }\end{array}$ & $\begin{array}{l}\text { Does not account for kinetic } \\
\text { details such as backdiffusion } \\
\text { or lymphatic drainage }\end{array}$ \\
\hline & $\begin{array}{l}\text { Evaluation of vascular } \\
\text { leak }\end{array}$ & $\begin{array}{l}\text { Uses microscopy to visualize } \\
\text { movement of injected tracer } \\
\text { Extravasates labeled tracers } \\
\text { such as dextrans and } \\
\text { Griffonia simplicifolia lectins } \\
\text { to detect vessel perfusion and } \\
\text { leak }\end{array}$ & $\begin{array}{l}\text { Light, fluorescence, or electron } \\
\text { microscopy can be used to evaluate } \\
\text { vascular leak } \\
\text { Dextrans of different sizes can be } \\
\text { used to evaluate the contribution of } \\
\text { different pathways to the leak response }\end{array}$ & $\begin{array}{l}\text { Requires tissue manipulation } \\
\text { Individual vessels may not } \\
\text { be representative of entire } \\
\text { vascular beds }\end{array}$ \\
\hline & $\begin{array}{l}\text { Intravital microscopy } \\
\text { of vascular beds }\end{array}$ & $\begin{array}{l}\text { Extravasates labeled tracers } \\
\text { to measure thin tissue } \\
\text { preparations }\end{array}$ & $\begin{array}{l}\text { Identifies sites of leak and can } \\
\text { quantify extent of extravasated tracer }\end{array}$ & $\begin{array}{l}\text { Requires tissue manipulation } \\
\text { and is difficult to use for long- } \\
\text { term studies }\end{array}$ \\
\hline
\end{tabular}

